\title{
Evaluation of the volatility basis-set approach for the simulation of organic aerosol formation in the Mexico City metropolitan area
}

\author{
A. P. Tsimpidi ${ }^{1}$, V. A. Karydis ${ }^{1}$, M. Zavala ${ }^{2}$, W. Lei ${ }^{2}$, L. Molina ${ }^{2}$, I. M. Ulbrich ${ }^{3}$, J. L. Jimenez ${ }^{3}$, and S. N. Pandis ${ }^{4,5}$ \\ ${ }^{1}$ Institute of Chemical Engineering and High Temperature Chemical Processes, Foundation for Research and Technology \\ Hellas, Patras, Greece \\ ${ }^{2}$ Department of Earth, Atmospheric and Planetary Sciences, Massachusetts Institute of Technology (MIT) and Molina Center \\ for Energy and the Environment (MCE2), La Jolla, CA 92037, USA \\ ${ }^{3}$ Department of Chemistry and Biochemistry, and CIRES, University of Colorado, Boulder, CO, USA \\ ${ }^{4}$ Department of Chemical Engineering, University of Patras, Patras, Greece \\ ${ }^{5}$ Department of Chemical Engineering, Carnegie Mellon University, Pittsburgh, PA 15213, USA
}

Received: 25 May 2009 - Published in Atmos. Chem. Phys. Discuss.: 22 June 2009

Revised: 12 November 2009 - Accepted: 19 November 2009 - Published: 20 January 2010

\begin{abstract}
New primary and secondary organic aerosol modules have been added to PMCAMx, a three dimensional chemical transport model (CTM), for use with the SAPRC99 chemistry mechanism based on recent smog chamber studies. The new modelling framework is based on the volatility basis-set approach: both primary and secondary organic components are assumed to be semivolatile and photochemically reactive and are distributed in logarithmically spaced volatility bins. This new framework with the use of the new volatility basis parameters for low- $\mathrm{NO}_{\mathrm{x}}$ and high- $\mathrm{NO}_{\mathrm{x}}$ conditions tends to predict 4-6 times higher anthropogenic SOA concentrations than those predicted with the older generation of models. The resulting PMCAMx-2008 was applied in Mexico City Metropolitan Area (MCMA) for approximately a week during April 2003 during a period of very low regional biomass burning impact. The emission inventory, which uses as a starting point the MCMA 2004 official inventory, is modified and the primary organic aerosol (POA) emissions are distributed by volatility based on dilution experiments. The predicted organic aerosol (OA) concentrations peak in the center of Mexico City, reaching values above $40 \mu \mathrm{g} \mathrm{m}^{-3}$. The model predictions are compared with the results of the Positive Matrix Factorization (PMF) analysis of the Aerosol Mass Spectrometry (AMS) observations. The model reproduces both Hydrocarbon-like Organic
\end{abstract}

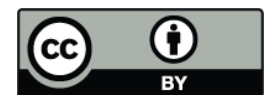

Correspondence to: S. N. Pandis (spyros@chemeng.upatras.gr)
Aerosol (HOA) and Oxygenated Organic Aerosol (OOA) concentrations and diurnal profiles. The small OA underprediction during the rush-hour periods and overprediction in the afternoon suggest potential improvements to the description of fresh primary organic emissions and the formation of the oxygenated organic aerosols, respectively, although they may also be due to errors in the simulation of dispersion and vertical mixing. However, the AMS OOA data are not specific enough to prove that the model reproduces the organic aerosol observations for the right reasons. Other combinations of contributions of primary and secondary organic aerosol production rates may lead to similar results. The model results strongly suggest that, during the simulated period, transport of OA from outside the city was a significant contributor to the observed OA levels. Future simulations should use a larger domain in order to test whether the regional OA can be predicted with current SOA parameterizations. Sensitivity tests indicate that the predicted OA concentration is especially sensitive to the volatility distribution of the emissions in the lower volatility bins.

\section{Introduction}

Anthropogenic air pollution is an increasingly serious problem for public health, global climate and ecosystems. Organic aerosol (OA) contributes approximately $20-50 \%$ to the total fine particulate mass at continental mid-latitudes

Published by Copernicus Publications on behalf of the European Geosciences Union. 
(Saxena and Hildemann, 1996; Putaud et al., 2004; Murphy et al., 2006; Zhang et al., 2007). Approximately half of the total aerosol mass in Mexico City is organic (Chow et al., 2002; Edgerton et al., 1999; Salcedo et al., 2006; DeCarlo et al., 2008; Aiken et al., 2009). PM $_{2.5}$ in urban Mexico City during March 1999 had an average organic carbon (OC) concentration of $10 \mu \mathrm{g} \mathrm{m}^{-3}$ (Chow et al., 2002). These levels are comparable to those observed in Los Angeles (Schauer et al., 1996; Docherty et al., 2008) and in three Chinese megacities, Beijing, Shanghai and Guangzhou (Feng et al., 2006). Although OA accounts for a large fraction of the $\mathrm{PM}_{2.5}$ concentration, the contributions of primary and secondary organic aerosol have been difficult to quantify (e.g. Hallquist et al., 2009; de Gouw and Jimenez, 2009). Organic aerosol originates from many different natural and anthropogenic sources and processes. Primary organic aerosol (POA) has been traditionally defined as the OA emitted into the atmosphere in particle form, e.g. from fossil fuel and biomass combustion, while secondary organic aerosol (SOA) is formed from gaseous precursors through gas-phase (Jacobson et al., 2000; Seinfeld et al., 2003; NARSTO, 2003), particle phase (Jang et al., 2002), or aqueous-phase reactions (Claeys et al., 2004; Blando, 2000). Due to their different origins and formation mechanisms, fresh POA and SOA usually have different chemical and microphysical properties (Mircea et al., 2002; Kerminen et al., 2000; Cruz et al., 1997; Kavouras et al., 2002; Zhang et al., 2005a; Aiken et al., 2008). Therefore, to design effective fine particle control strategies and to better evaluate the roles of organic aerosols in regional and global climate, we must understand the concentrations, properties and sources of these two organic aerosol types (NARSTO, 2003).

Spectroscopic techniques, including Fourier transform infrared (FTIR) spectroscopy (Allen et al., 1994; Blando et al., 1998) and nuclear magnetic resonance (NMR) (Decesari et al., 2000), have been used to characterise the functional group composition of bulk aerosol organics or their water-soluble fraction. Mass spectrometry techniques have been widely used in aerosol analysis because of their universal, extremely sensitive and rapid detection of aerosol components (McKeown et al., 1991; Suess and Prather, 1999). Among these, the Aerodyne Aerosol Mass Spectrometer (AMS) (Jayne et al., 2000; Jimenez et al., 2003) has been the most commonly used over the last few years. It is capable of quantitatively measuring the size-resolved mass concentrations of organic aerosols with a time resolution of minutes (e.g. Allan et al., 2003a; Takegawa et al., 2005; Jimenez et al., 2003; Zhang et al., 2005b). Good correlation between the mass concentrations of organic aerosols measured by an AMS and the organic carbon concentrations measured by thermal-optical Carbon Analyzers has been observed in various locations, including Pittsburgh (Zhang et al., 2005b), Tokyo (Takegawa et al., 2005), and off the New England coast (Bates et al., 2005; de Gouw et al., 2005).
Zhang et al. (2005a) developed a custom principal component analysis of AMS organic spectra that can identify and quantify broad organic aerosol "classes" that have different temporal and mass spectral signatures, and quantified two types of organic aerosols, hydrocarbon-like (HOA) and oxygenated (OOA), which together accounted for almost all the OA mass measured by the AMS during the PAQS study in Pittsburgh. HOA has similar AMS mass spectra to those of hydrocarbon mixtures in fresh primary OA, while OOA has high oxygen content and correlates with secondary tracers (Zhang et al., 2005a). In addition, recent work using the positive matrix factorization (PMF) method (Paatero and Tapper, 1994; Paatero, 1997) has allowed the identification of additional detail on primary and secondary sources/components at urban locations in Europe (Lanz et al., 2007) and North America (Ulbrich et al., 2009; Aiken et al., 2008, 2009; Nemitz et al., 2008).

Chemical transport models (EPA, 2009; Environ, 2008) have traditionally treated POA emissions as non-volatile and non-reactive, while SOA compounds are modelled as semi-volatile products of the oxidation of volatile precursors (Chung and Seinfeld, 2002; Kanakidou et al., 2005). With few exceptions, further oxidation of either POA or SOA, if treated at all, is modelled with an ad-hoc constant timescale for conversion of hydrophobic to hydrophilic material irrespective of oxidant availability and particle reactivity (Cooke et al., 1999). However, POA is clearly semi-volatile and undergoes gas-particle partitioning in the atmosphere as a function of its volatility, background OA (Robinson et al., 2007; Lipsky et al., 2006) and temperature (Kuhn et al., 2005; Huffman et al., 2008, 2009b). In addition, several recent field studies have shown that SOA formed downwind of metropolitan areas may be strongly underestimated by current models based on "traditional" SOA precursors and chamber yields (de Gouw et al., 2005; Volkamer et al., 2006; Kleinman et al., 2008; Docherty et al., 2008; Matsui et al., 2009; Dzepina et al., 2009). The formation of SOA in Mexico City is similar to that observed in other locations such as the Northeast US, Tokyo, or the Po Valley (Kleinman et al., 2008; de Gouw et al., 2008; de Gouw and Jimenez, 2009). The "traditional" secondary organic precursors include biogenic compounds (monoterpenes, sesquiterpenes, and isoprene) and anthropogenic compounds (mainly aromatics). In addition, recent work has suggested that chemical aging of semivolatile and intermediate volatile organic compounds (SVOCs and IVOCs) either emitted directly or resulting from the evaporation of particles (Robinson et al., 2007), or generated from VOCs (Lane et al., 2008a) may be an important and previously neglected pool of precursors for SOA formation and growth as well. Products with high vapour pressures can be oxidized to species with lower vapour pressures that can condense into the aerosol phase (Donahue et al., 2006). These chemical reactions can lead to continued SOA growth after complete precursor consumption as products undergo further oxidation (Kroll et al., 2006; $\mathrm{Ng}$ et al., 2006). 
Shrivastava et al. (2008) used the chemical transport model PMCAMx to investigate the effects of gas-particle partitioning and photochemical aging of primary emissions on organic aerosol concentrations in the Eastern United States. Lane et al. (2008a, b) used a new framework for modelling the secondary organic aerosol formation in the Eastern United States based on the SOA volatility basis-set approach (Donahue et al., 2006; Stanier et al., 2008) instead of the two-product approach (Odum et al., 1996) used in existing models. Nevertheless, there are no reported efforts of combining all these new findings in a single CTM and applying it in a polluted area with high concentrations of both fresh and aged secondary and primary organic aerosols. Trying to compare the results of such an application with the analysis of the AMS measurements can help evaluate the current state of understanding the organics and at the same time can assist in the interpretation of measurements from field campaigns.

In this work, we explicitly simulate the volatility of all organic compounds, including both primary emissions and secondary reaction products, and also model gas-phase reactions of semivolatile material. Each reaction time step alters the volatility distribution and, thus, the total organic aerosol mass. $\mathrm{NO}_{\mathrm{x}}$-dependent $\mathrm{SOA}$ yields based on smog chamber studies are also included in the updated SOA module (Lane et al., 2008a). The traditional terminology used to describe the major OA components needs to be extended to be compatible with the proposed modelling framework. We will be using the term POA to describe primary organic aerosol material that did not undergo chemical reactions during its atmospheric lifetime. SOA from semivolatile species, "S-SOA", is defined as the emitted semivolatile organic material with initial saturation concentration less or equal to $10^{2} \mu \mathrm{g} \mathrm{m}^{-3}$ (all volatilities in this paper are at $298 \mathrm{~K}$ ) which moved to the gas phase, was oxidized and re-condensed to the aerosol phase. S-SOA was also referred to as OPOA in some previous works (Shrivastava et al., 2008; Donahue et al., 2009). The current model does not simulate heterogeneous oxidation (reaction of gas-phase oxidants with particle-phase molecules) which is often also referred to as OPOA. SOA from VOCs, "V-SOA", will be the OA formed in the atmosphere from the oxidation of the volatile organic compounds ("traditional" SOA precursors with $C^{*}>10^{6} \mu \mathrm{g} \mathrm{m}^{-3}$ ). Finally, SOA from intermediate volatility species, "I-SOA", will be the OA formed in the atmosphere from the oxidation of intermediate volatility species (non-traditional SOA precursors with $10^{3} \leq \mathrm{C}^{*} \leq 10^{6} \mu \mathrm{g} \mathrm{m}^{-3}$ ). The oxidation products of all compounds that remained in the gas phase can be further oxidized and can condense in the aerosol phase. Therefore, the model simulates three types of oxygenated OA based on the initial volatility of the corresponding precursor compounds: S-SOA (precursor $\mathrm{C}^{*} \leq 10^{2} \mu \mathrm{g} \mathrm{m}^{-3}$ ), ISOA $\left(10^{3} \leq \mathrm{C}^{*} \leq 10^{6} \mu \mathrm{g} \mathrm{m}^{-3}\right)$ and V-SOA $\left(\mathrm{C}^{*}>10^{6} \mu \mathrm{g} \mathrm{m}^{-3}\right)$.

The model is applied in the Mexico City Metropolitan Area for approximately a week during 12-16 April 2003, as part of the MCMA-2003 field campaign (Molina et al.,
2007). The predictions of the model for the main species in gas phase $\left(\mathrm{CO}, \mathrm{NO}_{\mathrm{x}}, \mathrm{VOCs}\right)$ during this simulation period have been extensively evaluated against measurements during the MCMA-2003 campaign by Lei et al. (2007, 2008, 2009). The OA model predictions for this period are presented and are compared with measurements taken from the CENICA supersite by Salcedo et al. (2006). Moreover, in order to evaluate our current state of understanding the formation and the composition of the organic mass, we compare PMCAMx predictions of OA components against AMS analysis results. Finally, the sensitivity of the proposed organic aerosol framework to the volatility distribution of the emissions is investigated.

\section{PMCAMx-2008 description}

PMCAMx is a three-dimensional chemical transport model which uses the framework of CAMx (Environ, 2003) and models the processes of horizontal and vertical advection, horizontal and vertical dispersion, wet and dry deposition, and gas phase chemistry. Dry deposition is modelled using the resistance model of Wesely (1989) assuming a Henry's law constant for all the organic condensable gasses equal to $2.7 \times 10^{3} \mathrm{M} \mathrm{atm}^{-1}$. In addition, three detailed aerosol modules are used: inorganic aerosol growth (Gaydos et al., 2003; Koo et al., 2003), aqueous phase chemistry (Fahey and Pandis, 2001), and SOA formation and growth. These modules employ a sectional approach that dynamically models the size evolution of each aerosol constituent across 10 size sections varying from $40 \mathrm{~nm}$ to $40 \mu \mathrm{m}$.

The chemical mechanism used is based on the SAPRC99 mechanism (Carter, 2000; Environ, 2003) and includes 211 reactions of 56 gases and 18 free radicals. The version of SAPRC99 used here has five lumped alkanes, two lumped olefins, two lumped aromatics, isoprene, a lumped monoterpene, and a lumped sesquiterpene species. Only the two highest molecular weight alkane species are considered V-SOA precursors because the other three consist of smaller hydrocarbons (Pandis et al., 1991). OLE1 contains all the terminal alkenes, while OLE2 consists of all the internal alkenes and cyclic alkenes. Table 1 lists the lumped VOC classes used in SAPRC99 the major compounds for each VOC class and the nine SAPRC99 surrogate VOCs that are considered V-SOA precursors.

\subsection{Organic aerosol modeling}

\subsubsection{Partitioning of primary emissions}

Emission inventories and models currently treat POA as nonreactive and non-volatile. However, the POA mass is highly sensitive to ambient conditions, including dilution and temperature (Lipsky and Robinson, 2006; Hildemann et al., 1989). The critical attribute controlling organic compound 
Table 1. Major compounds for each lumped VOC within SAPRC99.

\begin{tabular}{|c|c|c|c|}
\hline Species & Major Components & $\begin{array}{l}\text { Type of } \\
\text { source }\end{array}$ & $\begin{array}{l}\text { V-SOA } \\
\text { precursors }\end{array}$ \\
\hline ALK1 & Ethane, Methyl Formate & Anthropogenic & No \\
\hline ALK2 & $\begin{array}{l}\text { Propane, Cyclobutane, Ethyl Formate, } \\
\text { Methyl Acetate }\end{array}$ & Anthropogenic & No \\
\hline ALK3 & $\begin{array}{l}n \text {-Butane, Ethanol, Isobutane, Dimethyl } \\
\text { Butane, Dimethyl Pentane }\end{array}$ & Anthropogenic & No \\
\hline ALK4 & $\begin{array}{l}n \text {-Pentane, } n \text {-Hexane, Branched } \mathrm{C}_{5}-\mathrm{C}_{6} \\
\text { Alkanes, Cyclopetane, Trimethyl Butane, } \\
\text { Trimethyl Pentane, Isopropyl Alcohol, } \\
n \text {-Propyl Alcohol }\end{array}$ & Anthropogenic & Yes \\
\hline ALK5 & $\begin{array}{l}\mathrm{C}_{7}-\mathrm{C}_{22} n \text {-Alkanes, } \mathrm{C}_{6}-\mathrm{C}_{16} \text { Cycloalkanes, } \\
\text { Branched/Unspeciated } \mathrm{C}_{8}-\mathrm{C}_{18} \text { Alkanes }\end{array}$ & Anthropogenic & Yes \\
\hline OLE1 & Propene, $\mathrm{C}_{4}-\mathrm{C}_{15}$ Terminal Alkenes & Anthropogenic & Yes \\
\hline OLE2 & $\begin{array}{l}\text { Isobutene, } \mathrm{C}_{4}-\mathrm{C}_{15} \text { Internal Alkenes, } \\
\mathrm{C}_{6}-\mathrm{C}_{15} \mathrm{Cyclic} \text { or di-olefins, Styrenes }\end{array}$ & Anthropogenic & Yes \\
\hline ARO1 & $\begin{array}{l}\text { Toluene, Benzene, Ethyl Benzene, } \\
\mathrm{C}_{9}-\mathrm{C}_{13} \text { Monosubstituted Benzenes }\end{array}$ & Anthropogenic & Yes \\
\hline $\mathrm{ARO} 2$ & $\begin{array}{l}\text { Xylenes, Ethyl Toluenes, Dimethyl and } \\
\text { Trimethyl Benzenes, Ethylbenzenes, } \\
\text { Naphthalene, } C_{8}-C_{13} \text { Di-, Tri-, Tetra-, } \\
\text { Penta-, Hexa-substituted Benzenes, } \\
\text { Unspeciated } C_{10}-C_{12} \text { Aromatics }\end{array}$ & Anthropogenic & Yes \\
\hline TERP & $\begin{array}{l}\alpha \text {-pinene, } \beta \text {-pinene, Limonene, Carene, } \\
\text { Sabinene, other monoterpenes }\end{array}$ & Biogenic & Yes \\
\hline ISOP & Isoprene & Biogenic & Yes \\
\hline SESQ & Sesquiterpenes & Biogenic & Yes \\
\hline
\end{tabular}

partitioning is volatility. The modified PMCAMx-2008 accounts for partitioning of primary emissions using the same module used to calculate partitioning of any semivolatile organic species (Koo et al., 2003) assuming that the bulk gas and particle phases are in equilibrium and that all condensable organics form a pseudo-ideal solution (Odum et al., 1996). Nine surrogate species with saturation concentrations at room temperature ranging from $10^{-2}$ to $10^{6} \mu \mathrm{g} \mathrm{m}^{-3}$ are used following the approach of Shrivastava et al. (2008).

\subsubsection{Secondary organic aerosol formation from VOCs}

The modelling framework used in this work is based on the SOA volatility basis-set approach (Lane et al., 2008a) instead of the two-product approach used in existing models. This approach includes four species for V-SOA produced from anthropogenic VOCs, assuming an average molecular weight of $150 \mathrm{~g} \mathrm{~mol}^{-1}$, and four additional species resulting from the oxidation of biogenic VOCs, assuming an average molecular weight of $180 \mathrm{~g} \mathrm{~mol}^{-1}$ and using the basis set for their effective saturation concentrations at $298 \mathrm{~K}$ : $1,10,100,1000 \mu \mathrm{g} \mathrm{m}^{-3}$. The V-SOA module in PMCAMx has been updated in order to include anthropogenic aerosol yields, based on laboratory results from recent smog-chamber experiments ( $\mathrm{Ng}$ et al., 2006; Hildebrandt et al., 2009). Moreover, the updated V-SOA module incorporates $\mathrm{NO}_{\mathrm{x}}$-dependent SOA yields (Table 2) (Lane et al., 2008b). Under low- $\mathrm{NO}_{\mathrm{x}}$ conditions, the $\mathrm{RO}_{2}$ radicals react with other peroxy radicals to form a distribution of products with lower volatilities, resulting in higher SOA yields. At high- $\mathrm{NO}_{\mathrm{x}}$ conditions, the SOA yields are lower because aldehydes, ketones, and nitrates dominate the product distribution. Dzepina et al. (2009) report that the low-NOx pathway was negligible in downtown Mexico City during a case study from MCMA-2003, however, this is not likely the case outside the city. The enthalpy of vaporization is assumed to be independent of the $\mathrm{NO}_{\mathrm{x}}$ level due to the lack of relevant experimental data at high- $\mathrm{NO}_{\mathrm{x}}$ conditions.

\subsubsection{Chemical aging reactions}

Chemical reactions that change the volatility of the organics in the gas phase will change the organic aerosol mass by influencing their partitioning. In this new approach, all species (primary and secondary) are treated as chemically reactive. Primary organic gases (POG), formed due to evaporation of semivolatile POA in the atmosphere, are assumed to react with $\mathrm{OH}$ radicals reducing their volatility. The products of 
Table 2. SOA yield scenarios using a four-product basis set with saturation concentrations of $1,10,100$, and $1000 \mu \mathrm{g} \mathrm{m}^{-3}$ at $298 \mathrm{~K}_{\text {. }}$

\begin{tabular}{|c|c|c|c|c|c|c|c|c|c|}
\hline \multirow[t]{2}{*}{$\begin{array}{l}\text { V-SOA } \\
\text { precursors }\end{array}$} & \multicolumn{4}{|c|}{$\begin{array}{c}\text { Aerosol Yield }{ }^{1} \\
\text { High- } \mathrm{NO}_{\mathrm{x}} \text { Parameterization }\end{array}$} & \multicolumn{4}{|c|}{$\begin{array}{c}\text { Aerosol Yield } \\
\text { Low- } \mathrm{NO}_{\mathrm{x}} \text { Parameterization }\end{array}$} & \multirow{2}{*}{$\begin{array}{c}\text { Molecular } \\
\text { Weight } \\
\left(\mathrm{g} \mathrm{mol}^{-1}\right)\end{array}$} \\
\hline & 1 & 10 & 100 & 1000 & 1 & 10 & 100 & 1000 & \\
\hline ALK4 & 0.000 & 0.038 & 0.000 & 0.000 & 0.000 & 0.075 & 0.000 & 0.000 & 120 \\
\hline ALK5 & 0.000 & 0.150 & 0.000 & 0.000 & 0.000 & 0.300 & 0.000 & 0.000 & 150 \\
\hline OLE1 & 0.001 & 0.005 & 0.038 & 0.150 & 0.005 & 0.009 & 0.060 & 0.225 & 120 \\
\hline OLE2 & 0.003 & 0.026 & 0.083 & 0.270 & 0.023 & 0.044 & 0.129 & 0.375 & 120 \\
\hline ARO1 & 0.003 & 0.165 & 0.300 & 0.435 & 0.075 & 0.225 & 0.375 & 0.525 & 150 \\
\hline $\mathrm{ARO} 2$ & 0.002 & 0.195 & 0.300 & 0.435 & 0.075 & 0.300 & 0.375 & 0.525 & 150 \\
\hline ISOP & 0.001 & 0.023 & 0.015 & 0.000 & 0.009 & 0.030 & 0.015 & 0.000 & 136 \\
\hline SESQ & 0.075 & 0.150 & 0.750 & 0.900 & 0.075 & 0.150 & 0.750 & 0.900 & 250 \\
\hline TERP & 0.012 & 0.122 & 0.201 & 0.500 & 0.107 & 0.092 & 0.359 & 0.600 & 180 \\
\hline
\end{tabular}

${ }^{1}$ The SOA yields are based on an assumed density of $1.5 \mathrm{~g} \mathrm{~cm}^{-3}$.

this oxidation (secondary vapours) are allowed to partition between gas and particle phase according to their volatilities. This resulted in the formation of oxidized organic aerosol (referred to as S-SOA in this work).

Intermediate volatility species (IVOC), that are co-emitted with the POA but are never in the particle phase during the emission process, also age in the same way to form I-SOA (Robinson et al., 2007).

Chemical aging of organic condensable gases (OCG), generated from VOCs that are traditional SOA precursors, is an important source of OA as well. For both cases, aging is modelled with a gas-phase $\mathrm{OH}$ reaction with a rate constant of $4 \times 10^{-11} \mathrm{~cm}^{3} \mathrm{molec}^{-1} \mathrm{~s}^{-1}$ (Atkinson and Arey, 2003). Each reaction is assumed to reduce the volatility of the vapour material by one order of magnitude (i.e. shifting material from a $C^{*}$ of 100 to $10 \mu \mathrm{g} \mathrm{m}^{-3}$ ), with a small net increase in mass $(7.5 \%)$ to account for added oxygen. The proposed chemical aging is confined to the gas-phase according to the reactions below:

$$
\begin{aligned}
& \mathrm{POA}_{i}(\mathrm{p}) \leftrightarrow \mathrm{POG}_{i}(\mathrm{~g}) \\
& \mathrm{POG}_{i}(\mathrm{~g})+\mathrm{OH} \rightarrow 1.075 \mathrm{OPOG}_{i-1}(\mathrm{~g}) \\
& \mathrm{OPOG}_{i-1}(\mathrm{~g}) \leftrightarrow \mathrm{S}-\mathrm{SOA}_{i-1}(\mathrm{p}) \\
& \mathrm{IVOC}_{i}(\mathrm{~g})+\mathrm{OH} \rightarrow 1.075 \mathrm{IVOC}_{i-1}(\mathrm{~g}) \\
& \mathrm{IVOC}_{i-1}(\mathrm{~g}) \leftrightarrow \mathrm{I}-\mathrm{SOA}_{i-1}(\mathrm{p}) \\
& \mathrm{VOC} \mathrm{g})+\mathrm{OH} \rightarrow \sum_{i=1}^{n} \mathrm{a}_{i} \mathrm{OCG}_{i}(\mathrm{~g}) \\
& \mathrm{OCG}_{i}(\mathrm{~g})+\mathrm{OH} \rightarrow 1.075 \mathrm{OCG}_{i-1}(\mathrm{~g}) \\
& \mathrm{OCG}_{i-1}(\mathrm{~g}) \leftrightarrow V-\mathrm{SOA}_{i-1}(\mathrm{p})
\end{aligned}
$$

where $i$ is the corresponding volatility bin. The different aerosol types and chemical processes modelled in the proposed framework are illustrated in Fig. 1. Heterogeneous and condensed-phase reactions are not simulated explicitly in this framework but they could also play a role. The formation of SOA from glyoxal may be important in Mexico City (Volkamer et al., 2007, 2009; Dzepina et al., 2009), but is not considered explicitly in this study.

\subsection{Volatility-resolved OA emission inventory}

The emission inventory used is constructed based on the official emissions inventory of the MCMA for 2004 (CAM, 2006) which includes $\mathrm{PM}_{10}$ and $\mathrm{PM}_{2.5}$ mass emissions but without chemical speciation. Mobile sources are the most significant contributors to primary fine particle mass in the MCMA. The direct impact of local biogenic sources of VOCs in the urban area is small, although recent results suggest that the transport of biogenic SOA formed in the coastal mountain ranges may be an important source of regional SOA that impacts Mexico City (Hodzic et al., 2009), which would be represented here as part of the boundary condition OA. The official emission estimates of PM mass used in this study were obtained using the bottom-up approach that combines source-specific emissions and activity factors (CAM, 2006). The PM emissions from biogenic, mobile, point, and area sources were spatially and temporally distributed following the techniques described in Lei et al. (2007). Updated fine resolution population maps, road, street and digital highway data, along with the digitalization of point sources and most of the area emission sources considered in the emissions inventory, were combined with a Geographical Information System to construct spatially distributed gridded emission maps. The mass of PM from the official emissions inventory was partitioned using the PMF analysis of rush-hour measurements taken during the MCMA-2003 and MILAGRO/MCMA-2006 field campaigns using periods of high HOA and minimum secondary formation. In order to account for partitioning of primary organic emissions, the emission inventory for PMCAMx-2008 must 
Table 3. Parameters used to treat partitioning of POA emissions.

\begin{tabular}{lccccccccc}
\hline $\mathrm{C}^{*}$ at $298 \mathrm{~K}\left(\mu \mathrm{g} \mathrm{m}^{-3}\right)$ & 0.01 & 0.1 & 1 & 10 & $10^{2}$ & $10^{3}$ & $10^{4}$ & $10^{5}$ & $10^{6}$ \\
\hline $\begin{array}{l}\text { Fraction of emissions } \\
\text { (Basecase) }\end{array}$ & 0.03 & 0.06 & 0.09 & 0.14 & 0.18 & 0.30 & 0.40 & 0.50 & 0.80 \\
\hline $\begin{array}{l}\text { Fraction of emissions } \\
\text { (Low volatility case) }\end{array}$ & 0.06 & 0.12 & 0.18 & 0.28 & 0.36 & 0 & 0 & 0 & 0 \\
\hline $\begin{array}{l}\text { Fraction of emissions } \\
\text { (High volatility case) }\end{array}$ & 0.03 & 0.06 & 0.09 & 0.14 & 0.18 & 0.30 & 0.60 & 1.00 & 1.60 \\
\hline $\begin{array}{l}\text { Molecular weight } \\
\left(\mathrm{g} \mathrm{mol}^{-1}\right)\end{array}$ & 250 & 250 & 250 & 250 & 250 & 250 & 250 & 250 & 250 \\
\hline $\begin{array}{l}\Delta \mathrm{H} \\
(\mathrm{kJ} \mathrm{mol}\end{array}$ & 112 & 106 & 100 & 94 & 88 & 82 & 76 & 70 & 64 \\
\hline
\end{tabular}

\section{Formation of S-SOA}

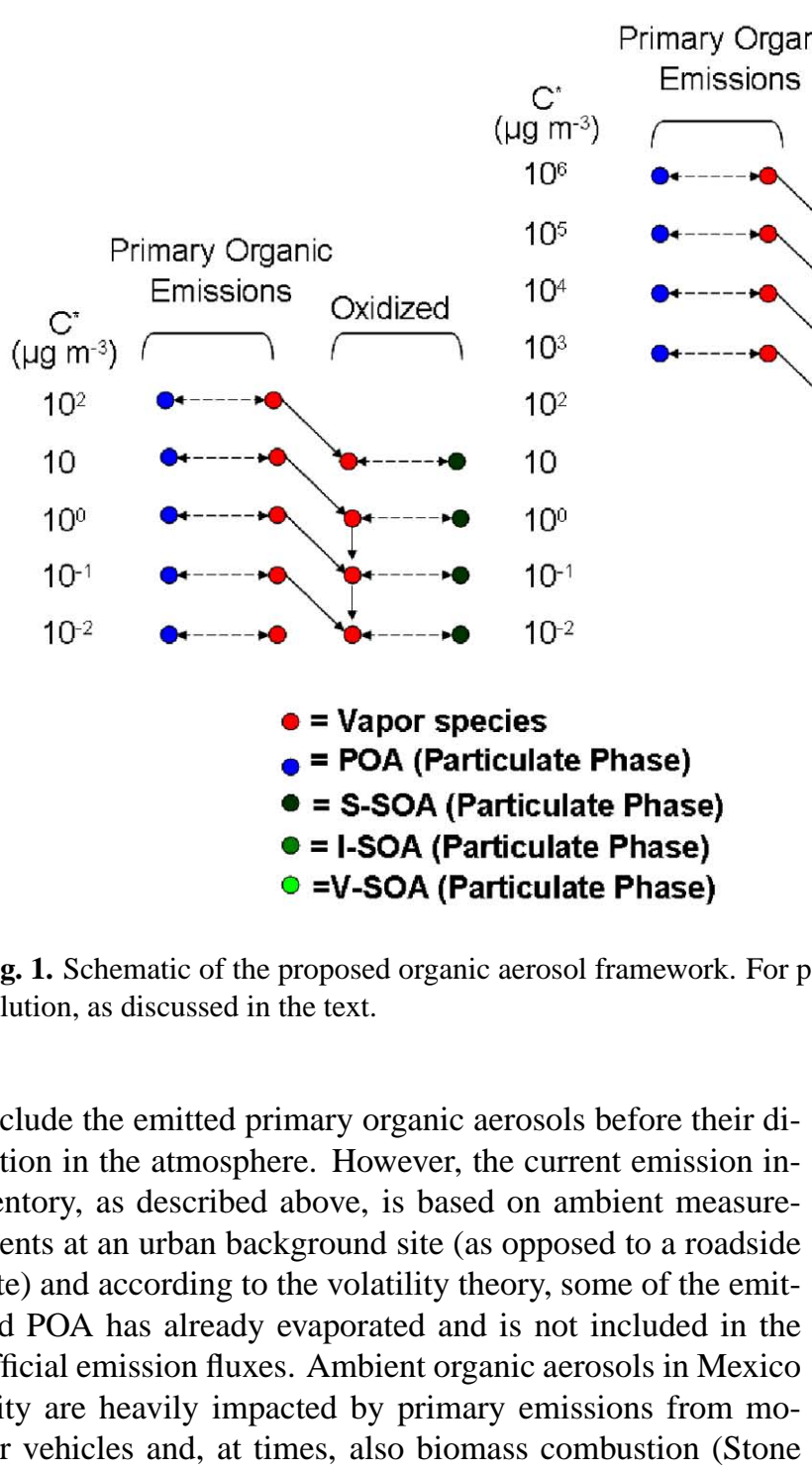
solution, as discussed in the text. include the emitted primary organic aerosols before their dilution in the atmosphere. However, the current emission inventory, as described above, is based on ambient measurements at an urban background site (as opposed to a roadside site) and according to the volatility theory, some of the emitted POA has already evaporated and is not included in the official emission fluxes. Ambient organic aerosols in Mexico City are heavily impacted by primary emissions from motor vehicles and, at times, also biomass combustion (Stone

\section{Formation of V-SOA}

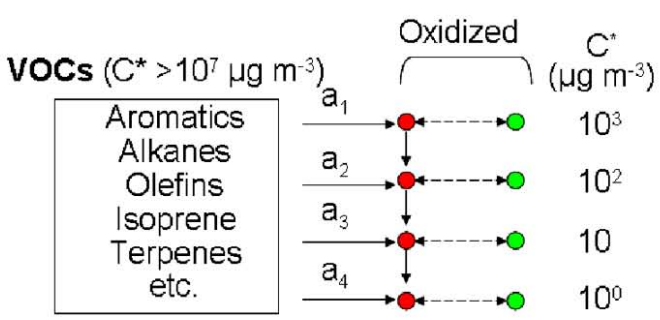

Fig. 1. Schematic of the proposed organic aerosol framework. For partitioning calculations, all organics are assumed to form a pseudo-ideal

et al., 2008; Aiken et al., 2009). Laboratory experiments, in which diesel exhaust and wood smoke emissions were measured at different levels of dilution, have shown that the measured primary organic aerosols in ambient conditions represent $15-40 \%$ of the primary organic aerosol actually emitted, depending on the ambient organic aerosol concentration and temperature (Lipsky and Robinson, 2006). Thermal denuder measurements in Mexico City during MILAGRO (Huffman et al., 2009a; Dzepina et al., 2009) have also shown that 


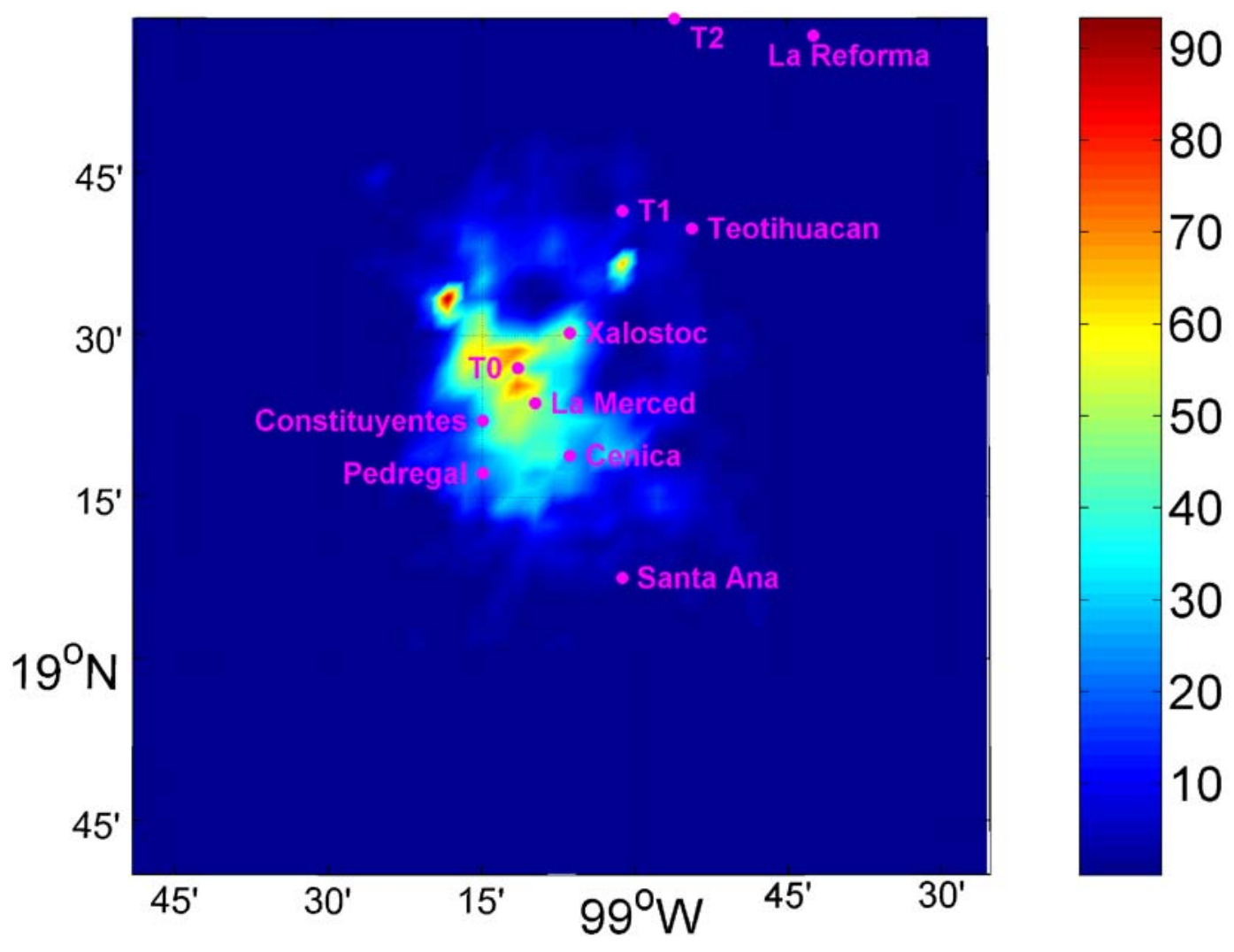

Fig. 2. Total primary organic aerosol emission rates $\left(\mathrm{kg} \mathrm{d}^{-1} \mathrm{~km}^{-2}\right)$ spatial distribution. These are assumed to be semivolatile in PMCAMx (their saturation concentration ranges from $10^{-2}$ to $10^{6} \mu \mathrm{g} \mathrm{m}^{-3}$ ) and a significant fraction of them (of the order of $60 \%$ given the temperature and the OA concentration in Mexico City) evaporates after emission and dilution.

POA in Mexico City is semivolatile. The average concentration of the organic aerosols in Mexico City was in the range of $20 \mu \mathrm{g} \mathrm{m}^{-3}$ during the MCMA-2003 campaign (Salcedo et al., 2006). In this range of organic aerosol ambient concentrations, the measured organic PM is approximately one third of the total emitted organic aerosols (Fig. 1a of Robinson et al., 2007). Therefore, in order to estimate the total semivolatile organic emissions, the OA particulate inventory is multiplied by a factor of 3 . Source test data for wood combustion, gasoline vehicles and diesel vehicles which used a sample train of quartz filters in combination with denuders and/or sorbents (Schauer et al., 1999, 2001, 2002) has shown that the mass of unmeasured IVOC vapours is between 0.25 to 2.8 times the existing primary OA emissions. In this work, the OA emissions were distributed by volatility (Table 3 ) using the volatility distributions of Shrivastava et al. (2008). This distribution was derived by fitting gas particle partitioning data for diesel exhaust and wood smoke assuming that the mass of unmeasured IVOC emissions is equivalent to 1.5 times the primary organic aerosol emissions. The total amount of material (POA+SVOC+IVOC) introduced in the model is 7.5 times the particle-phase POA emissions, which is identical to the factor calculated from partitioning theory and ambient data by Dzepina et al. (2009). This material totals 55 tons $\mathrm{d}^{-1}$, and the particle + gas phase SVOC material totals 22 tons $^{-1}$. The amount of new material introduced in the model as evaporated POA and IVOCs is poorly constrained as these species have not been measured in Mexico City. However, Sheehy et al. (2008) and Dzepina et al. (2009) reported that the new material introduced in this way is compatible with the observations of total $\mathrm{OH}$-reactivity and integrated C-H stretches measured with FTIR during MCMA2003 and in fact does not yet close the gap between the sum of speciated contributions and the total integrated measurements in both cases.

The result was a gridded emission inventory (Fig. 2) of nine lumped non-oxidized primary species (POA) and intermediate volatility species (IVOC) corresponding to volatility bins ranging from $10^{-2}$ to $10^{6} \mu \mathrm{g} \mathrm{m}^{-3}$ at $300 \mathrm{~K}$ (Fig. 3). The POA emissions are also distributed in six size sections ranging from $40 \mathrm{~nm}$ to $2.5 \mu \mathrm{m}$ (Fig. 4) with most of this mass $(96 \%)$ being in bins with a size less than $1 \mu \mathrm{m}$. The volatility distribution includes "nonvolatile" ( $\left.\mathrm{C}^{*} \leq 10^{-1} \quad \mu \mathrm{g} \mathrm{m}^{-3}\right)$, "semivolatile" (SVOC; $10 \mu \mathrm{g} \mathrm{m}^{-3} \leq \mathrm{C}^{*} \leq 10^{2} \mu \mathrm{g} \mathrm{m}^{-3}$ ), and "intermediate-volatility" (IVOC; $10^{3} \mu \mathrm{g} \mathrm{m}^{-3} \leq \mathrm{C}^{*} \leq 10^{6} \mu \mathrm{g} \mathrm{m}^{-3}$ ) organic compounds. 


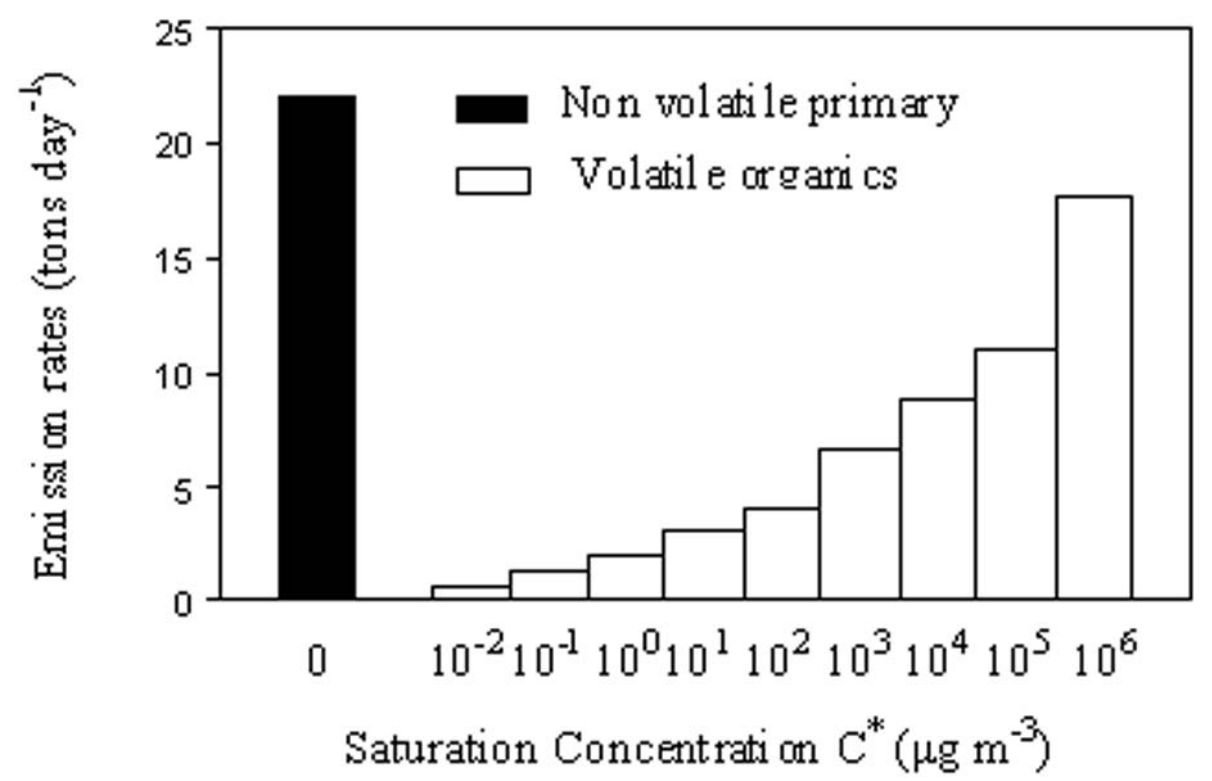

Fig. 3. Volatility distribution of primary organics. The non-volatile POA emissions are those used in the traditional non-volatile POA framework. The white bars are the estimated emissions in the volatility basis-set framework as described in the text. The sum of the white bars is 55 tons $\mathrm{d}^{-1}$.

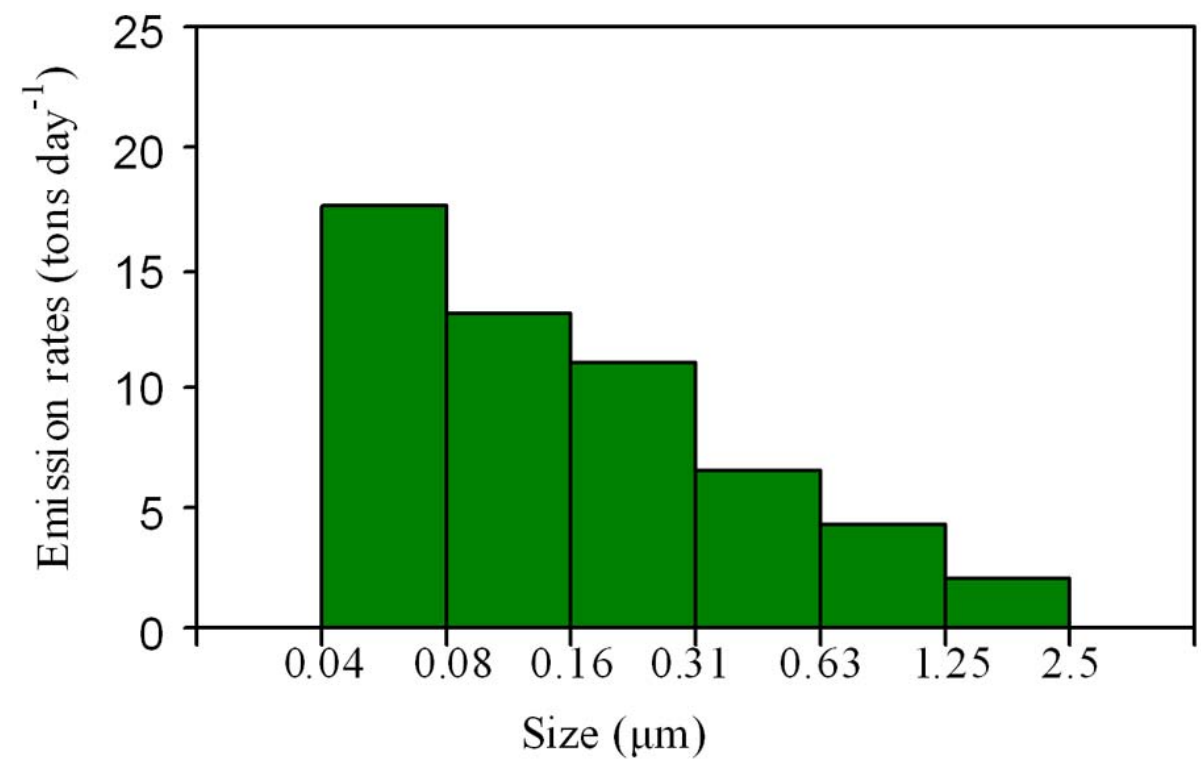

Fig. 4. Size distribution of primary organic emissions. The sum of the green bars is 55 tons $\mathrm{d}^{-1}$.

The majority of these emissions have a $C^{*} \geq 10^{3} \mu \mathrm{g} \mathrm{m}^{-3}$ and, therefore, exist largely in the gas phase at typical atmospheric conditions. Nevertheless, they might be important I-SOA precursors as their oxidation can produce compounds with lower vapour pressures. The effective saturation concentration, molecular weights and enthalpies of vapourization of these nine lumped species are listed in Table 3, based on fits of diesel and wood-smoke partitioning data (Lipsky and Robinson, 2006; Shrivastava et al., 2006). The use of these data to partition the OA emissions is a reasonable first approximation for the current application in MCMA as the mobile sources are the most significant contributors to primary fine particle mass in MCMA with biomass combustion also being an important contributor during specific periods but having only a small impact during the period analyzed here (Johnson et al., 2006). 
Table 4. Description of Mexico City Sites.

\begin{tabular}{|c|c|}
\hline Site and position & Site description \\
\hline 1. CENICA & MCMA-2003 Supersite located in the Autonomous \\
\hline $\left.19.358^{\circ} \mathrm{N}, 99.073^{\circ} \mathrm{W}\right)$ & $\begin{array}{l}\text { Metropolitan University campus Iztapalapa at the southeast } \\
\text { of the city. The traffic in the immediate vicinity of the site is } \\
\text { moderate and composed by old and new vehicles on paved } \\
\text { roads. }\end{array}$ \\
\hline 2. Constituyentes & Western suburban neighbourhood close to Chapultepec park. \\
\hline$\left(19.400^{\circ} \mathrm{N}, 99.210^{\circ} \mathrm{W}\right)$ & $\begin{array}{l}\text { Heavy traffic on paved roads composed by private cars and } \\
\text { heavy-duty diesel buses. }\end{array}$ \\
\hline $\begin{array}{l}\text { 3. La Merced } \\
\left(19.424^{\circ} \mathrm{N}, 99.119^{\circ} \mathrm{W}\right)\end{array}$ & $\begin{array}{l}\text { Central city section composed by a mix of residences, small } \\
\text { and medium commerce, light industries and a busy market. }\end{array}$ \\
\hline 4. La Reforma & Southwestern downwind site from Pachuca, city with \\
\hline$\left(19.976^{\circ} \mathrm{N}, 98.697^{\circ} \mathrm{W}\right)$ & $\begin{array}{l}245000 \text { inhabitants located to the northeast of Mexico City. } \\
\text { Rural site close to urban areas with reduced vehicular traffic } \\
\text { on paved and unpaved roads. }\end{array}$ \\
\hline $\begin{array}{l}\text { 5. Pedregal } \\
\left(19.325^{\circ} \mathrm{N}, 99.204^{\circ} \mathrm{W}\right)\end{array}$ & $\begin{array}{l}\text { Southwestern suburban neighbourhood with paved residential } \\
\text { roads lightly traveled. This site is in the prevailing downwind } \\
\text { direction from the center of the city. }\end{array}$ \\
\hline $\begin{array}{l}\text { 6. Santa Ana Tlacotenco } \\
\left(19.177^{\circ} \mathrm{N}, 98.990^{\circ} \mathrm{W}\right)\end{array}$ & $\begin{array}{l}\text { Rural site to the southwest of Mexico City, close to the gap } \\
\text { in the mountains at Amecameca. Paved and unpaved roads } \\
\text { with minimum traffic. }\end{array}$ \\
\hline $\begin{array}{l}\text { 7. Teotihucan } \\
\left(19.688^{\circ} \mathrm{N}, 98.870^{\circ} \mathrm{W}\right)\end{array}$ & $\begin{array}{l}\text { Northern upwind boundary site of Mexico City with } \\
\text { pollution influence from a large power plant and large } \\
\text { industries around the region. }\end{array}$ \\
\hline $\begin{array}{l}\text { 8. Xalostoc } \\
\left(19.527^{\circ} \mathrm{N}, 99.076^{\circ} \mathrm{W}\right)\end{array}$ & $\begin{array}{l}\text { Northeastern industrial section of the city with light to } \\
\text { medium industries. Heavy traffic on paved and unpaved } \\
\text { roads formed by a mix of new and old gasoline and diesel } \\
\text { vehicles. }\end{array}$ \\
\hline $\begin{array}{l}\text { 9. T0 } \\
\left(19.489^{\circ} \mathrm{N}, 99.148^{\circ} \mathrm{W}\right)\end{array}$ & $\begin{array}{l}\text { Urban background site located to the northwestern part of the } \\
\text { basin of Mexico City, used as one of the main supersites } \\
\text { during MILAGRO-2006. }\end{array}$ \\
\hline $\begin{array}{l}\text { 10. T1 } \\
\left(19.703^{\circ} \mathrm{N}, 98.982^{\circ} \mathrm{W}\right)\end{array}$ & $\begin{array}{l}\text { Suburban background site located around } 50 \mathrm{~km} \text { to the north } \\
\text { of Mexico City, in an area isolated from major urban } \\
\text { agglomerations but close to small populated agglomerations, } \\
\text { used as one of the main supersites during MILAGRO-2006. }\end{array}$ \\
\hline $\begin{array}{l}\text { 11. T2 } \\
\left(20.010^{\circ} \mathrm{N}, 98.909^{\circ} \mathrm{W}\right)\end{array}$ & $\begin{array}{l}\text { Regional background site located around } 90 \mathrm{~km} \text { to the north } \\
\text { of the city of Mexico, in the surroundings of a farm isolated } \\
\text { from major urban agglomerations. }\end{array}$ \\
\hline
\end{tabular}

\section{Model application}

PMCAMx is applied in the Mexico City Metropolitan Area for approximately a week during 12-16 April 2003. The Mexico City Metropolitan Area (MCMA) is situated inside a basin at $2200 \mathrm{~m}$ altitude. The basin is surrounded by high mountains on three sides. The model domain, shown in Fig. 5 , covers a $156 \times 156 \times 6 \mathrm{~km}$ region in the MCMA with $3 \times 3 \mathrm{~km}$ grid resolution and 15 vertical layers. Information about selected sites in Mexico City appearing in this figure is listed in Table 4. The first day of the simulation has been excluded from the analysis to limit the effect of the initial conditions on the results. The values of the OA concentrations at the boundaries of the domain, approximately $7 \mu \mathrm{g} \mathrm{m}^{-3}$ in the west, $10 \mu \mathrm{g} \mathrm{m}^{-3}$ in the east, $6 \mu \mathrm{g} \mathrm{m}^{-3}$ in the south and $5.5 \mu \mathrm{g} \mathrm{m}^{-3}$ in the northern boundary, were chosen based on results of the GISS-II' global CTM for April (Racherla et al., 2006). Please note that all concentrations in this paper are under ambient pressure and temperature conditions. These levels represent the average OA concentrations over the Central Mexican Plateau approximately $50 \mathrm{~km}$ outside Mexico City and should not be confused with the larger-scale background concentrations of Mexico (reflecting concentrations over the lower to middle troposphere over the Pacific Ocean) of much less than $0.5 \mu \mathrm{g} \mathrm{m}^{-3}$ (DeCarlo et al., 2008; Fast et al., 2009). These boundary condition values are consistent with the ground measurements in T2 during MILAGRO (very close to the northern boundary of the domain) by Doran 


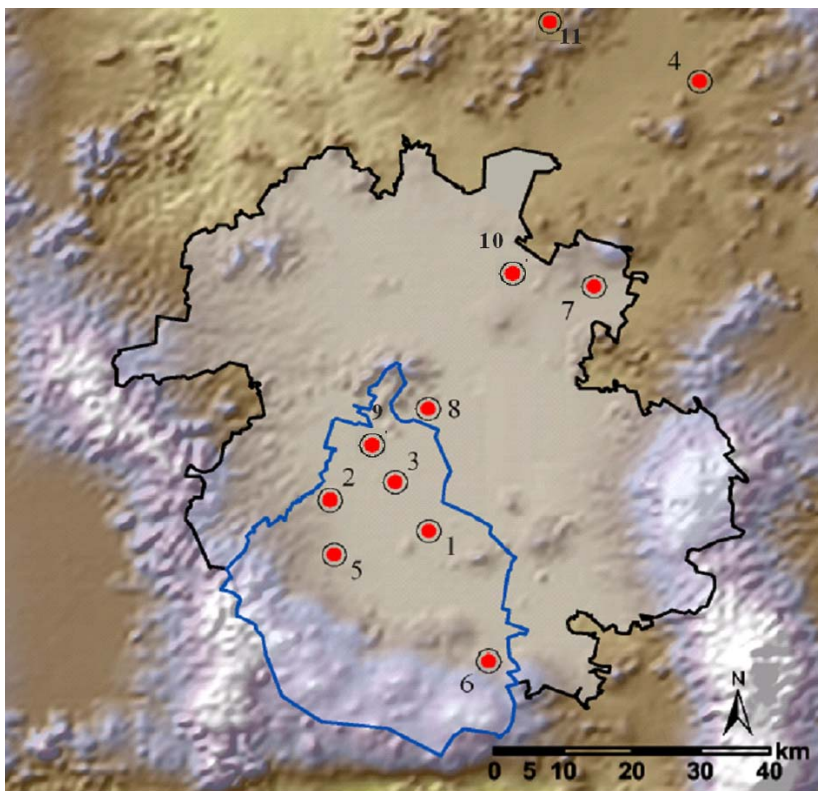

Fig. 5. Modelling domain used for the simulation. Selected sites in Mexico City, appearing in this figure, are listed in Table 4. The shadow limited by the black contour represents the boundary of the so called "Mexico City Metropolitan Area", while the blue contour limits the Federal District.

et al. (2007) who reported average OA concentrations of approximately $8 \mu \mathrm{g} \mathrm{m}^{-3}$ (assuming an $\mathrm{OM} / \mathrm{OC}$ ratio of 1.6) for the month of March 2006. Because the biomass burning emissions are not included in the current inventory, they are implicitly provided to the model as a part of the boundary conditions; however this impact should be minor as regional biomass burning impacts were small during this period (Johnson et al., 2006). The organic mass transported into the domain is assumed to be a mixture of aged primary and secondary organic aerosols (Zhang et al., 2007; DeCarlo et al., 2008), treated as nonvolatile and non-reactive, and is referred to hereinafter as "long range transport oxygenated OA". The model assumes that V-SOA, I-SOA and S-SOA form a pseudo-ideal solution together with the long range transport oxygenated OA and, therefore, are allowed to partition into this pre-existing organic aerosol.

Inputs to the model include horizontal wind components, temperature, pressure, water vapor, vertical diffusivity, clouds and rainfall, all based on the work of de Foy et al. (2005) using the meteorological model MM5 (Grell et al., 1995). The simulated month, April, is a transition month between the hot, dry season and the wet season (Jauregui, 1988). The first two days of simulation had unperturbed westerlies with weak anticyclonic conditions to the south and a strong subtropical jet just to the north of the MCMA. The remaining days are dominated by a low level anticyclonic circulation over central southern Mexico and westerly winds in the north. This lead to subsidence over the Mexico basin with weak surface winds favourable to the development of thermally driven circulations (de Foy et al., 2005).

\section{Predicted organic aerosol concentrations}

The episode average predicted $\mathrm{PM}_{1} \mathrm{OA}$ ground concentration during 13-16 April is depicted in Fig. 6. Because of the relatively high boundary condition concentrations assumed in the basecase simulation, the average predicted OA levels in the area exceed everywhere $6 \mu \mathrm{g} \mathrm{m}^{-3}$. The average concentrations of OA peak in the centre of Mexico City with values in the range of $20 \mu \mathrm{g} \mathrm{m}^{-3}$. Hourly concentrations peak as high as $40 \mu \mathrm{g} \mathrm{m}^{-3}$. The predicted OM consists of POA, SOA (sum of V-SOA, S-SOA, and I-SOA) and transported OA. The corresponding episode average contributions of these components to the $\mathrm{PM}_{1}$ organic mass are shown in Fig. 7. POA represents on average one third of the predicted $\mathrm{OA}$ in the centre of the city with concentrations up to $8 \mu \mathrm{g} \mathrm{m}^{-3}$, but its contribution drops rapidly to $10 \%$ or less of the total (concentration less than $1 \mu \mathrm{g} \mathrm{m}^{-3}$ ) on the edges of the urban area. Local SOA is predicted to be the dominant OA component in the city centre (Fig. 7c) with its contribution to the total OA ranging from $20 \%$ to $50 \%$. The concentrations of S-SOA and I-SOA are around $1 \mu \mathrm{g} \mathrm{m}^{-3}$ each inside the city and less than that outside (Fig. $7 \mathrm{f}$ and e). Finally, V-SOA contributes on average roughly $40 \%$ of the OA inside the city and $20 \%$ of the OA outside of it. The V-SOA produced from locally emitted organic vapours has concentrations around $6 \mu \mathrm{g} \mathrm{m}^{-3}$ in the centre of Mexico City and is dominated by V-SOA produced from aromatic hydrocarbons (Fig. 8). On average, 23\% of total V-SOA is the result of oxidation of ARO1 (toluene, benzene, ethyl benzenes, etc), 33\% of ARO2 (xylenes, ethyl toluenes, dimethyl and trimethyl benzenes, etc), $1 \%$ of ALK4, 14\% of ALK5 (large alkenes), $5 \%$ of OLE1, $18 \%$ of OLE2, $4 \%$ of TERP, $0.5 \%$ of ISOP, and $1.5 \%$ of SESQ. Overall, this new framework with the use of the new volatility basis parameters for low- $\mathrm{NO}_{\mathrm{x}}$ and high- $\mathrm{NO}_{\mathrm{x}}$ conditions (Fig. 10 in Hildebrandt et al., 2009), which far exceed the historical parameters used in previous models (Koo et al., 2003; Volkamer et al., 2006), predicts 4-6 times higher anthropogenic SOA concentrations inside Mexico City than those predicted with older generation of models such as Koo et al. (2003). The use of the new anthropogenic aerosol yields increased the predicted SOA by approximately three times while the addition of the aging reactions in the SOA mechanism approximately doubled the predicted SOA concentration. Finally, the implementation of the $\mathrm{NO}_{\mathrm{x}}$ dependence of the aerosol yields resulted on average in a $15 \%$ decrease of the predicted SOA concentration. The $\mathrm{NO}_{\mathrm{x}}$-related decrease is more pronounced in the urban centre where the SOA is formed under high- $\mathrm{NO}_{\mathrm{x}}$ conditions (Dzepina et al., 2009), and less in the surrounding areas. The importance of transported OA is depicted in Fig. 7b. It dominates, as expected, the area outside the city with contribution 
Table 5. Comparison of PMCAMx predictions with hourly averages of PMF analysis of AMS measurements taken at CENICA supersite during 13-16 April 2003 (96 data points).

\begin{tabular}{|c|c|c|c|c|c|c|c|}
\hline & $\begin{array}{c}\text { Mean } \\
\text { Observed } \\
\pm \text { Standard } \\
\text { Deviation } \\
\left(\mu \mathrm{g} \mathrm{m}^{-3}\right)\end{array}$ & $\begin{array}{c}\text { Mean } \\
\text { Predicted } \\
\pm \text { Standard } \\
\text { Deviation } \\
\left(\mu \mathrm{g} \mathrm{m}^{-3}\right)\end{array}$ & $\begin{array}{c}\text { Mean } \\
\text { Absolute } \\
\text { Gross } \\
\text { Error } \\
\left(\mu \mathrm{g} \mathrm{m}^{-3}\right)\end{array}$ & $\begin{array}{c}\text { Mean } \\
\text { Bias } \\
\left(\mu \mathrm{g} \mathrm{m}^{-3}\right)\end{array}$ & $\begin{array}{c}\text { Normalized } \\
\text { Mean Error } \\
(\%)\end{array}$ & $\begin{array}{c}\text { Normalized } \\
\text { Mean Bias } \\
(\%)\end{array}$ & $\begin{array}{c}\text { Root } \\
\text { Mean } \\
\text { Square } \\
\text { Error } \\
\left(\mu \mathrm{g} \mathrm{m}^{-3}\right)\end{array}$ \\
\hline $\mathrm{PM}_{1} \mathrm{OA}$ & $15 \pm 5.6$ & $16.1 \pm 7.5$ & 5.29 & 1.06 & 35 & 7 & 7.08 \\
\hline $\mathrm{PM}_{1} \mathrm{HOA}$ & $3.2 \pm 2.3$ & $3 \pm 1.6$ & 0.78 & -0.25 & 24 & -8 & 0.95 \\
\hline $\mathrm{PM}_{1} \mathrm{OOA}$ & $10.3 \pm 2.9$ & $11.4 \pm 5.5$ & 2.57 & 1.10 & 25 & 11 & 3.37 \\
\hline
\end{tabular}

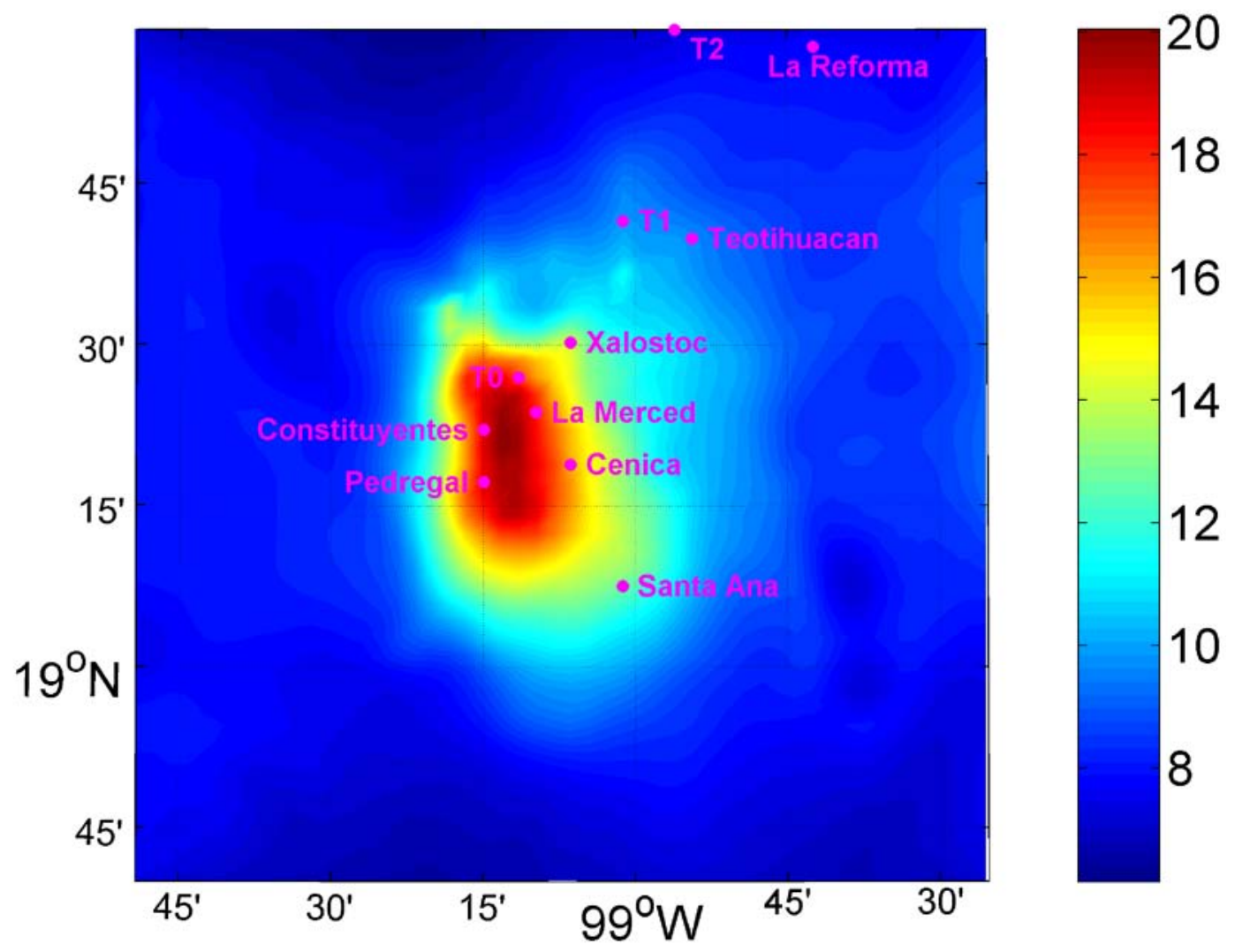

Fig. 6. Predicted episode average ground-level concentrations of $\mathrm{PM}_{1}$ organic mass $\left(\mu \mathrm{g} \mathrm{m}^{-3}\right)$ during 13-16 April 2003.

up to $90 \%$ to the total OA close to the domain boundaries, but even within the urban area it represents a significant component of OA ( $40 \%$ on average of the total OA). Obviously, its fractional contribution decreases significantly during the periods with high $\mathrm{OA}$ levels inside the city and in these cases it represents less than one quarter of the total OA. The sensitivity of these results to the boundary conditions for OA is discussed in more detail in a subsequent section.

\section{Model performance evaluation for organic PM}

Model predictions were compared with measurements that took place during the Mexico City Metropolitan Area field campaign at a highly instrumented "Supersite" located at the "Centro Nacional de Investigacion y Capacitacion Ambiental" (CENICA), in southeast Mexico City (Salcedo et al., 2006, 2007; Volkamer et al., 2006, 2007; Johnson et al., 2008; Dzepina et al., 2009). CENICA is located in a mixed commercial-residential area with relatively few industries or congested road networks, and was thus assumed to 

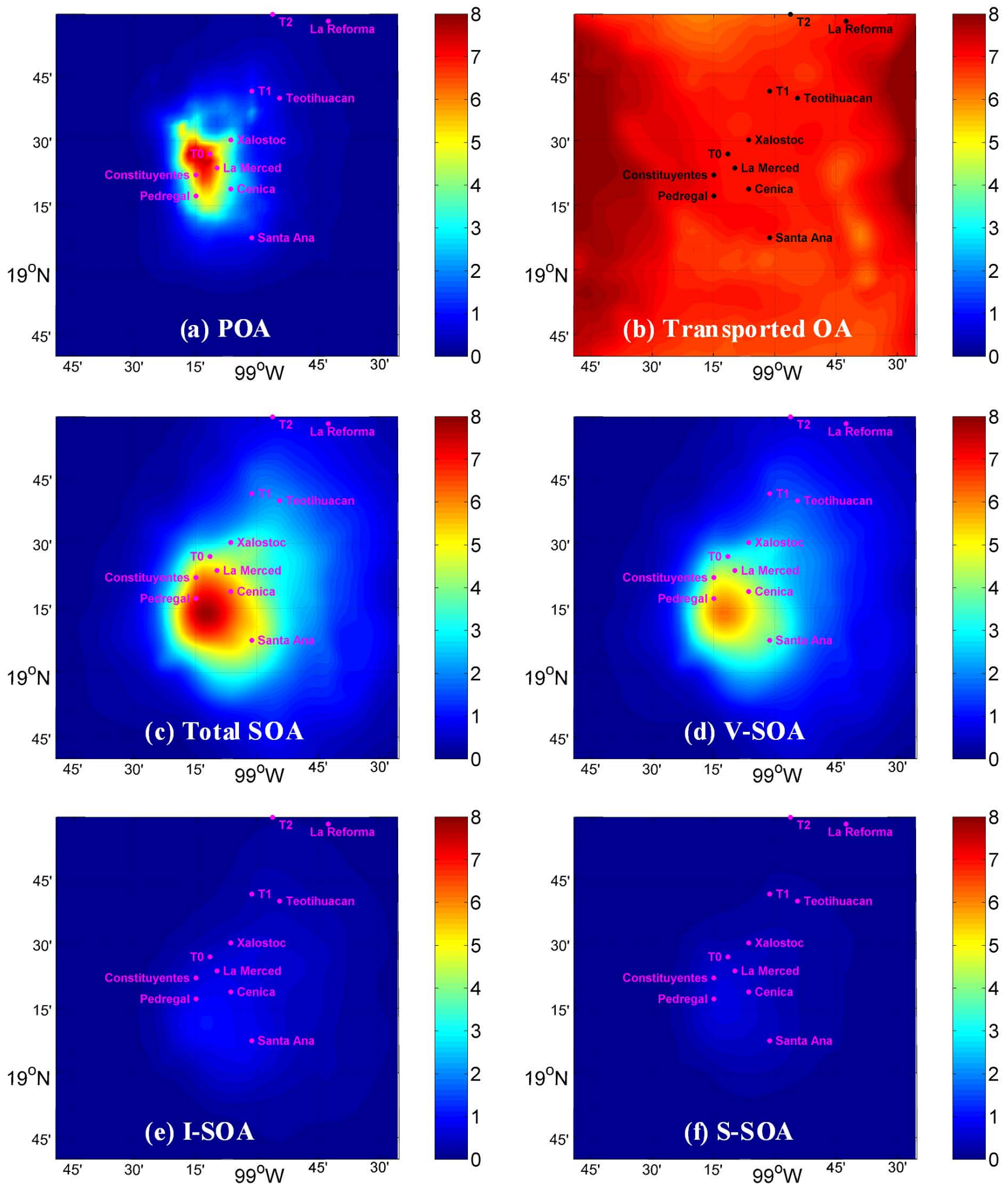

Fig. 7. Predicted episode average ground-level concentrations $\left(\mu \mathrm{g} \mathrm{m}^{-3}\right)$ of (a) POA, (b) OA transported into the domain from other areas, (c) Total SOA (V-SOA+I-SOA+S-SOA), (d) V-SOA, (e) I-SOA and (f) S-SOA during 13-16 April 2003. 


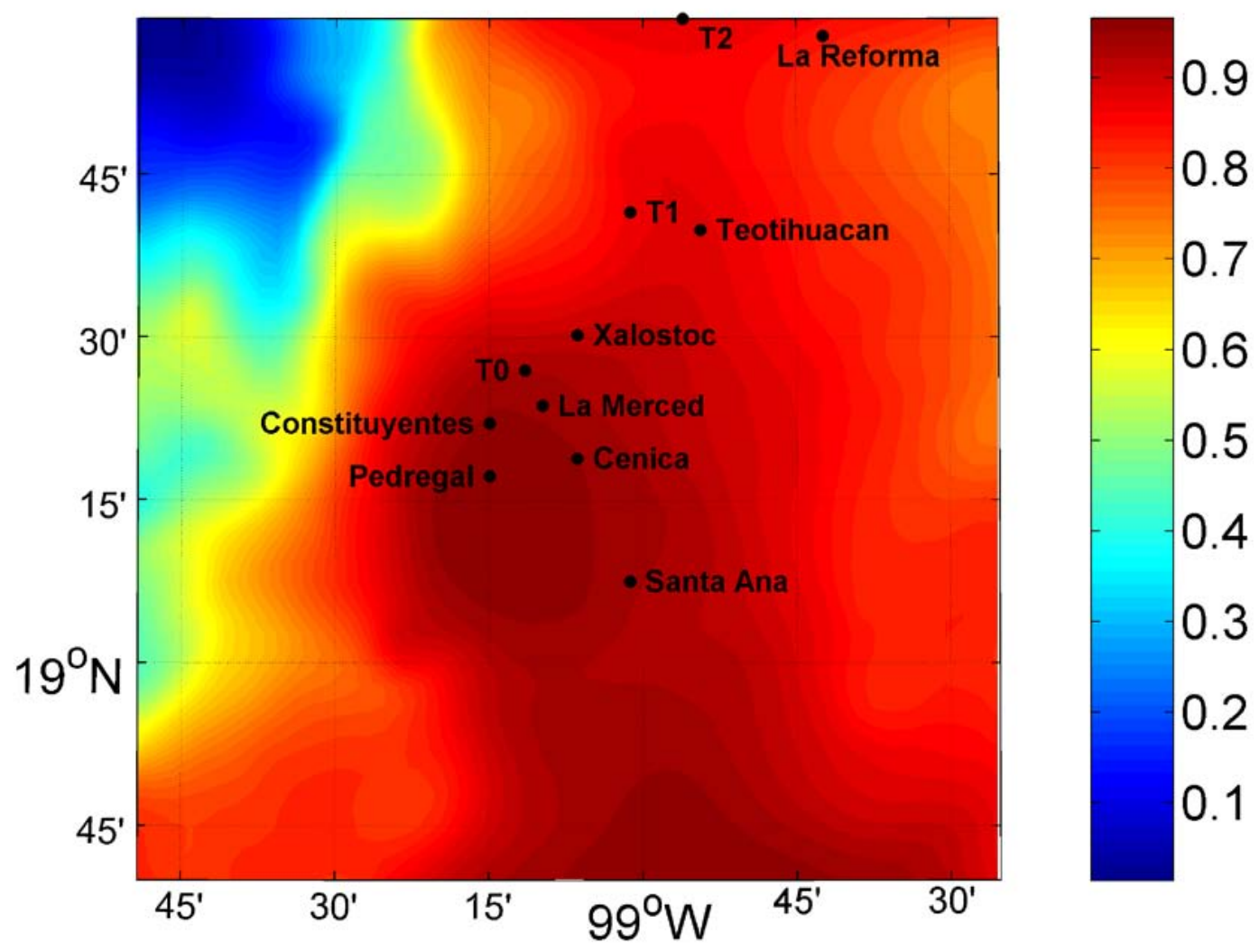

Fig. 8. Predicted episode average ground-level fractional contribution of anthropogenic V-SOA to PM 1 total V-SOA during $13-16$ April 2003.

be representative of ambient urban conditions. During the MCMA-2003 campaign, an Aerodyne Quadrupole Aerosol Mass Spectrometer (Q-AMS) was deployed at CENICA, measuring the size-resolved aerosol chemical composition of non-refractory species in particles smaller than about $1 \mu \mathrm{m}$ $\left(\mathrm{NR}-\mathrm{PM}_{1}\right)$ with $4 \mathrm{~min}$ time resolution (Jayne et al., 2000; Jimenez et al., 2003). Positive matrix factorization (PMF) of AMS organic spectra allowed the separation of ambient urban OA mass into several components (Ulbrich et al., 2009). As $\mathrm{OH}$ is the oxidant dominating the chemistry of oxygenated organic aerosol precursor species in this area, we have also evaluated the ability of the model to reproduce the observed $\mathrm{OH}$ concentrations (Fig. 9). OH radical concentrations were measured by Laser Induced Fluorescence (LIF) (Shirley et al., 2006) and were recently corrected for a calibration error (Mao et al., 2009; Dzepina et al., 2009). The measured $\mathrm{OH}$ diurnal profile is reproduced by the model in the afternoons, but the model underpredicts the observed $\mathrm{OH}$ in the morning and especially at night. Only the underprediction at night is outside the combined uncertainties of the model and the observations. The 24-h average $\mathrm{OH}$ concentration is underpredicted by approximately $20 \%$.
The mean bias (MB), mean absolute gross error (MAGE), normalized mean bias (NMB), normalized mean error (NME) and the root mean square error (RMSE) were also calculated (Table 5) to assess the model performance:

$$
\begin{aligned}
& \mathrm{MAGE}=\frac{1}{N} \sum_{i=1}^{N}\left|P_{i}-O_{i}\right| \\
& \mathrm{MB}=\frac{1}{N} \sum_{i=1}^{N}\left(P_{i}-O_{i}\right) \\
& \mathrm{NME}=\frac{\sum_{i=1}^{N}\left|P_{i}-O_{i}\right|}{\sum_{i=1}^{N} O_{i}} \\
& \mathrm{NMB}=\frac{\sum_{i=1}^{N}\left(P_{i}-O_{i}\right)}{\sum_{i=1}^{N} O_{i}} \\
& \mathrm{RMSE}=\left[\frac{1}{N} \sum_{i=1}^{N}\left(P_{i}-O_{i}\right)^{2}\right]^{\frac{1}{2}}
\end{aligned}
$$




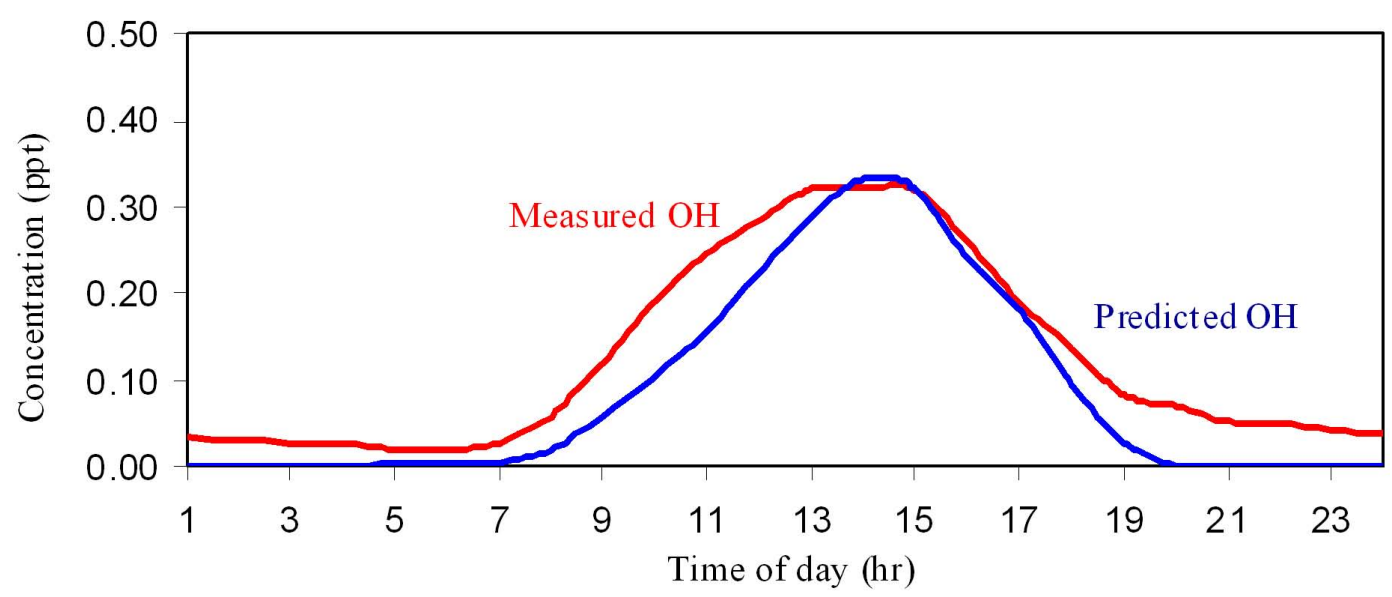

Fig. 9. Comparison of model diurnal predictions for surface concentrations of $\mathrm{OH}$ against observations taken during the MCMA campaign in 13-16 April 2003 at CENICA.

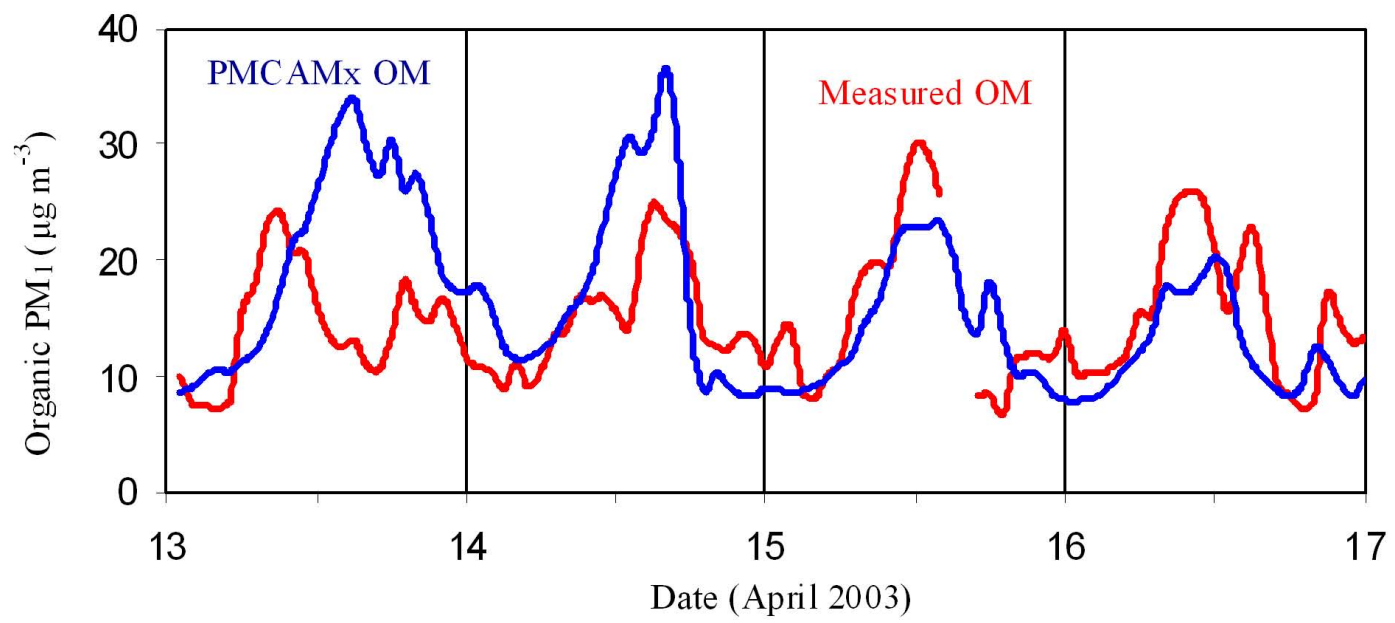

Fig. 10. Comparison of model predictions with hourly measurements for total $\mathrm{PM}_{1}$ organic mass concentration taken during the MCMA campaign in 13-16 April 2003 at CENICA.

where $P_{i}$ is the predicted value of the pollutant concentration, $O_{i}$ is the observed value of the pollutant at the same time and $N$ is the total number of the predictions used for the comparison. NME (in \%) and MAGE (in $\mu \mathrm{g} \mathrm{m}^{-3}$ ) give an estimation of the overall discrepancy between predictions and observations, while NMB (in \%) and $\mathrm{MB}$ (in $\mu \mathrm{g} \mathrm{m}^{-3}$ ) are sensitive to systematic errors. RMSE (in $\mu \mathrm{g} \mathrm{m}^{-3}$ ) is the root of the mean square error which incorporates both the variance of the prediction and its bias. Additional details for the above evaluation metrics can be found in Yu et al. (2006). The predicted and the measured values are compared for every single hour during the simulation period, instead of the usual comparison of daily average PM values (Morris et al., 2006).

\subsection{Total organic aerosol mass}

According to the measurements the average $\mathrm{PM}_{1} \mathrm{OA}$ concentration during 13-16 April 2003 was $15 \mu \mathrm{g} \mathrm{m}^{-3}$ (Fig. 10) at CENICA. OM measurements show high daily variation $\left(\mathrm{SD}=5.6 \mu \mathrm{g} \mathrm{m}^{-3}\right.$ ) and peak values mainly during the morning rush-hour and the early afternoon (up to $30 \mu \mathrm{g} \mathrm{m}^{-3}$ ). The first peak is associated with primary organic aerosols while the second with the afternoon photochemistry and the formation of the secondary organic aerosols. The comparison of PMCAMx-2008 predictions with hourly average measurements during the same period is encouraging (Fig. 10) with the exception of 13 April when PMCAMx tends to overpredict the OM concentration during the afternoon. The NME and the NMB are $35 \%$ and $7 \%$, respectively, while excluding the data points from 13 April the NME and the NMB are $28 \%$ and $-4 \%$, respectively. In order to investigate if PMCAMx 


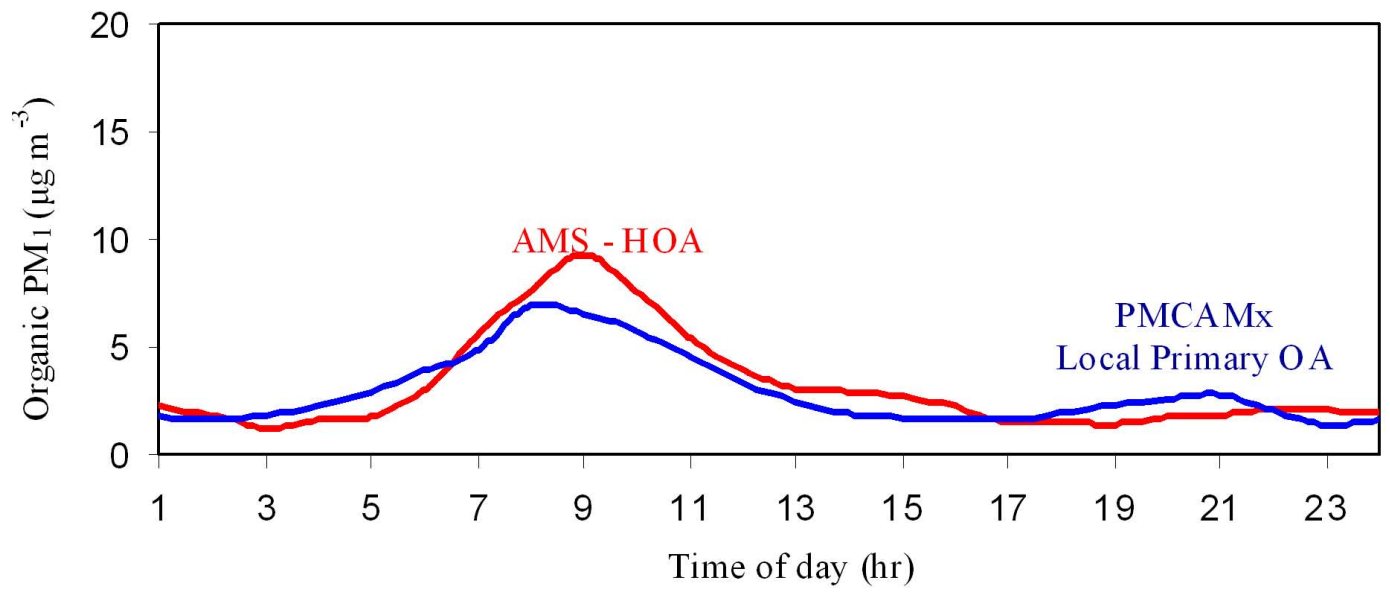

Fig. 11. Comparison of model episode average diurnal predictions for $\mathrm{PM}_{1}$ local primary organic aerosols against AMS-HOA taken during the MCMA campaign in 13-16 April 2003 at CENICA.

is predicting the total organic mass for the right reasons, the predicted components of the total organic mass are compared against the corresponding results of the AMS-PMF analysis in the next section focusing on the diurnal episode average profiles of the components of the organic mass.

\subsection{Local primary organics}

According to laboratory and field studies, the AMS HOA is typically associated with combustion exhaust (Alfarra et al., 2004; Zhang et al., 2004, 2005a; Canagaratna et al., 2004; Allan et al., 2003; Ulbrich et al., 2009; Dzepina et al., 2009; Aiken et al., 2009). HOA often increases during the rush-hours in urban areas. In addition, the size distribution of HOA in urban areas almost always displays a prominent ultrafine mode that is clearly associated with vehicular emissions (Zhang et al., 2004, 2005a; Alfarra, 2004; Canagaratna et al., 2004; Allan et al., 2003). In view of these facts, HOA appears to be an AMS mass spectral fingerprint for primary combustion particles from urban sources, and also including particles from other relatively reduced sources such as meat cooking and trash (plastic) burning (Mohr et al., 2009). Therefore, the AMS HOA is compared with PMCAMx POA which is the fraction of the emissions that is in the aerosol phase without undergoing any chemical reaction (Fig. 11). Both $\mathrm{PM}_{1}$ HOA and POA values always exceed $2 \mu \mathrm{g} \mathrm{m}^{-3}$ and increase significantly during the rushhour with a peak value at $09 \mathrm{~h} 00$. The AMS HOA is higher than the POA by $0.2 \mu \mathrm{g} \mathrm{m}^{-3}$ on average with the highest discrepancy at $08 \mathrm{~h} 00$. This encouraging agreement between the diurnal patterns $\left(\mathrm{RMSE}=0.95 \mu \mathrm{g} \mathrm{m}^{-3}\right.$ ) indicates that the new approach for the primary organics combined with the volatility-based emission inventory is, in general, consistent with the AMS technique of estimating the local primary OA. The reasonable agreement of modelled vs. measured POA is not surprising since the measured HOA had been used in the specification of the POA inventory, as discussed above. The reasonable prediction of POA is also consistent with the modelling results of Fast et al. (2009) using WRF-CHEM and of Hodzic et al. (2009) using CHIMERE for MILAGRO2006.

\subsection{Oxygenated organic aerosol}

OOA is an important fraction of the organic particles in Mexico City. It contains a more volatile and less processed oxygenated OA fraction which shows high correlation with photochemical products such as $\mathrm{O}_{3}, \mathrm{O}_{\mathrm{x}}$, glyoxal and ammonium nitrate (Volkamer et al., 2006, 2007; Aiken et al., 2008; Lanz et al., 2007; Ulbrich et al., 2009; Dzepina et al., 2009). However, a significant fraction of the OOA consists of more oxygenated organics (Aiken et al., 2008) which are assumed here to have initially formed far from Mexico City. Therefore, the AMS OOA is compared with the sum of the PMCAMx V-SOA, I-SOA, S-SOA and transported oxygenated OA (Fig. 12). Both episode average diurnal profiles suggest that the oxygenated organic aerosol concentration always exceeds $7 \mu \mathrm{g} \mathrm{m}^{-3}$ on average, and increases in the afternoon when photochemistry is more intense. PMCAMx suggests that there is a relatively high background highlighting the potential importance of sources outside Mexico City for the average conditions, and consistent with the results of Hodzic et al. (2009). AMS and PMCAMx give high oxygenated organic aerosol concentrations in the early afternoon with the highest at $15 \mathrm{~h} 00\left(16 \mu \mathrm{g} \mathrm{m}^{-3}\right.$ and $20 \mu \mathrm{g} \mathrm{m}^{-3}$, respectively). Generally, PMCAMx reproduce well the AMS OOA values in the morning (the NME excluding the afternoon data points is $11 \%$ ) while in the afternoon the model predictions exceed the AMS values (the NMB for the afternoon data points is $36 \%$ ). The correlation between the two patterns $(\mathrm{NME}=25 \%$ and $\mathrm{NMB}=11 \%)$ suggests that the volatility theory and parameters along with the new higher 


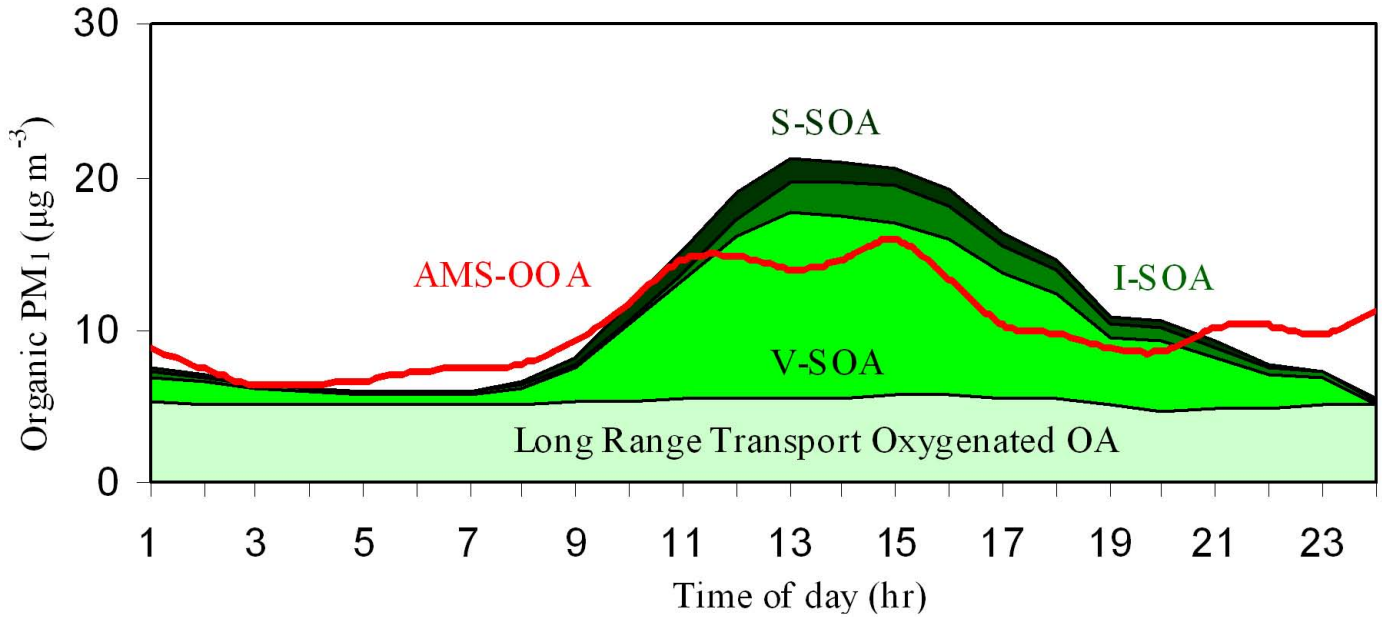

Fig. 12. Comparison of model episode average diurnal predictions for $\mathrm{PM}_{1}$ oxygenated organic aerosols (sum of Long Range Transport Oxygenated OA, V-SOA, I-SOA, and S-SOA) against AMS-OOA taken during the MCMA campaign in 13-16 April 2003 at CENICA.

SOA anthropogenic yields are in general consistent with the AMS OOA levels in Mexico City for this period. Dzepina et al. (2009) obtained similar results with measurements during a different period of MCMA-2003, but with a larger contribution of S-SOA and I-SOA, relative to V-SOA. The different relative contributions (and perhaps also the slight overprediction of total OOA in the present work) arise from the aging of V-SOA, which is not implemented in the Dzepina et al. (2009) work. However, it is important to note that the AMS measurements with the current analysis techniques lack the specificity to distinguish between V-SOA, I-SOA and S-SOA, and that the amounts of precursors for S-SOA and I-SOA are poorly constrained. Thus, the reasonable agreement observed here should not be overinterpreted, as it mainly indicates that the combination of amounts, yields and reaction rates of V-SOA, I-SOA and S-SOA precursors used here can produce an amount of OOA consistent with the measurements, but confirming the relative contribution of the different SOA precursors requires additional research.

\section{Sensitivity to changes in emissions and boundary conditions}

Uncertain inputs for the model include the volatility distribution for the existing primary organic aerosol emissions, the amount of the unmeasured intermediate volatile organic compound emissions and the boundary conditions. Three different simulations were conducted in order to bound the model predictions for plausible ranges of these parameters. A low volatility case, where the emissions in the low volatility bins $\left(\mathrm{C}^{*}: 10^{-2}-10^{2} \mu \mathrm{g} \mathrm{m}^{-3}\right)$ are doubled and the emissions in the high volatility bins are set to 0 , a high volatility case, where the emissions of the additional IVOCs in the high volatility bins $\left(10^{4}-10^{6} \mu \mathrm{g} \mathrm{m}^{-3}\right)$ are doubled (Table 3), and a low boundary condition case where the boundary conditions are reduced by half.

Using the low volatility distribution, the partitioning of the emissions favours the particulate phase. In this case, PMCAMx predicts that the fraction of the emissions that did not undergo any chemical reaction, POA, is two times higher than using the basecase distribution. The model in this case overpredicts the estimated HOA (not shown). Moreover, in the low volatility case, the vapour material that is produced from the partitioning of the emissions is lower (expecting less $\mathrm{S}$-SOA) but at the same time is distributed in lower volatility bins and consequently its oxidation will favour the S-SOA formation. These opposite effects results in an almost zero change of S-SOA. PMCAMx does not produce any I-SOA as in the low volatility case there are no IVOC emissions. The absence of these emissions can potentially increase the formation of V-SOA as there are more oxidants available to react with the V-SOA precursors (consistent with the results of Sheehy et al. (2008), who estimated that SVOCs and IVOCs contribute about $10 \%$ of the $\mathrm{OH}$ reactivity during MCMA2003). PMCAMx predicts that the magnitude of this V-SOA increase is almost $0.5 \mu \mathrm{g} \mathrm{m}^{-3}$.

For the high volatility case, fewer oxidants are available, due to the increase of the additional IVOCs, resulting in a decrease of V-SOA by approximately $0.3 \mu \mathrm{g} \mathrm{m}^{-3}$. The extra IVOC emissions result in $0.5 \mu \mathrm{g} \mathrm{m}^{-3}$ more I-SOA than the basecase predictions. Finally, in the high volatility case, the amount of the emissions with saturation concentration up to $10^{3} \mu \mathrm{g} \mathrm{m}^{-3}$ remained unchanged resulting in similar concentrations of POA and S-SOA with the basecase results. The sensitivity of OA and its components to this change is, therefore, relatively small. 


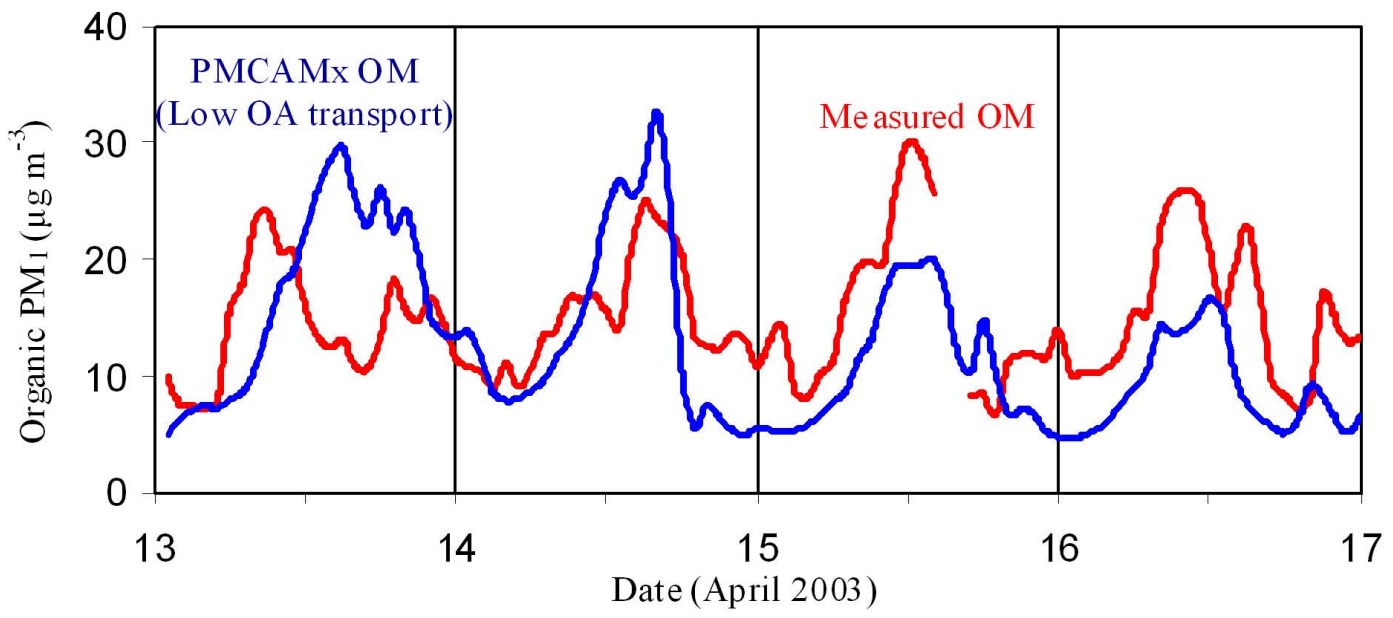

Fig. 13. Comparison of model predictions in the low boundary conditions case with hourly measurements for total $\mathrm{PM}_{1}$ organic mass concentration taken during the MCMA campaign in 13-16 April 2003 at CENICA.

In the third sensitivity simulation, the $50 \%$ reduction of the boundary conditions resulted in an almost linear response of the background organic concentration, which is not surprising since this OA is assumed to be non-reactive and nonvolatile. In particular, the average background organic concentration of the entire domain in the base case simulation was predicted to be $6 \mu \mathrm{g} \mathrm{m}^{-3}$, while in the low boundary conditions case is predicted to be approximately $3 \mu \mathrm{g} \mathrm{m}^{-3}$. Figure 13 shows the comparison between the measured and the predicted total organic mass concentrations at CENICA for lower boundary conditions during 13-16 April 2003. In this case, the model underpredicts the observed OA on 14 and 15 April, although the agreement improves for 12 and 13 April. During the nighttime period, the same pattern is observed. During nighttime, the primary organic aerosol emissions are limited and the photochemical processes are not active in the model, but they are (through $\mathrm{OH}$ and $\mathrm{NO}_{3}$ ) in reality. Therefore, it is difficult to evaluate which set of boundary conditions performs better, and probably the boundary conditions should be variable in time. The influence of the long range transport concentration remains significant for the low boundary condition case as it represents approximately $20 \%$ of the total organic aerosol concentration at CENICA.

\section{Conclusions}

In this work, the effects of the semi-volatile nature of primary organic emissions and photochemical aging of primary and secondary organics on OA levels in MCMA were simulated using a modified 3-D Chemical Transport Model PMCAMx. The primary organic aerosol emissions were distributed among a set of volatility bins based on the fits to measured partitioning behaviour of diesel exhaust and wood smoke data. The modified PMCAMx model allowed the primary emissions to partition in the atmosphere according to the absorptive partitioning theory. Gas phase low-volatility organics from partitioning of SOA and POA were photochemically aged in the atmosphere via reaction with the $\mathrm{OH}$ radical. Aging was assumed to shift the organic mass to lower volatility bins generating condensed phase oxidized organic aerosols from SVOC (S-SOA), IVOC (I-SOA) and VOC (V-SOA).

The model predictions are compared with PMF analysis of Aerodyne Aerosol Mass Spectrometry (AMS) observations from the MCMA 2003 campaign. The comparison of the predicted and measured component organic mass diurnal profiles is encouraging. There is a small, missing part during the rush-hours and an overprediction during the afternoon. According to this comparison, there is a relatively high background highlighting the importance of the boundary conditions around Mexico City for at least this period. Therefore, in order to reduce the effect of the boundaries, the model domain should be expanded for the future applications. The new approach indicates that the volatility distribution of the aerosols is important, suggesting that instead of measuring fixed POA emission factors one must measure the volatility distribution of the emissions. The IVOC emissions play an important role not only to the formation of I-SOA but of V-SOA too, as they can affect the amount of the available oxidants. Finally, the distribution of OA emissions to the low volatility bins appears to be extremely important for the predicted POA as it has great impact to the initial partitioning between the aerosol and the gas phase. Measurements of the amounts and speciation of primary SVOCs and IVOCs, as well as more specific measurements of the sources of SOA are needed to further constrain and evaluate the model results. 
Acknowledgements. This research was supported by the European Union and the 7th Framework Programme under the project MEGAPOLI (Grant agreement no. 212520). A. P. Tsimpidi, V. A. Karydis, M. Zavala, and W. Lei were supported by scholarships from the Molina Center for Energy and the Environment. JLJ and IMU were supported by NOAA OGP (NA08OAR4310565), NSF (ATM-0528634), and DOE (BER, ASP program, DEFG0208ER64627). LTM was supported by NSF (ATM-0528227).

Edited by: C. E. Kolb

\section{References}

Aiken, A. C., DeCarlo, P. F., Krol, J. H., et al.: O/C and OM/OC Ratios of Primary, Secondary, and Ambient Organic Aerosols with High Resolution Time-of-Flight Aerosol Mass Spectrometry, Environ. Sci. Technol., 42, 4478-4485, 2008.

Aiken, A. C., Salcedo, D., Cubison, M. J., Huffman, J. A., DeCarlo, P. F., Ulbrich, I. M., Docherty, K. S., Sueper, D., Kimmel, J. R., Worsnop, D. R., Trimborn, A., Northway, M., Stone, E. A., Schauer, J. J., Volkamer, R. M., Fortner, E., de Foy, B., Wang, J., Laskin, A., Shutthanandan, V., Zheng, J., Zhang, R., Gaffney, J., Marley, N. A., Paredes-Miranda, G., Arnott, W. P., Molina, L. T., Sosa, G., and Jimenez, J. L.: Mexico City aerosol analysis during MILAGRO using high resolution aerosol mass spectrometry at the urban supersite (T0) - Part 1: Fine particle composition and organic source apportionment, Atmos. Chem. Phys., 9, 66336653, 2009, http://www.atmos-chem-phys.net/9/6633/2009/.

Alfarra, M. R., Coe, H., Allan, J. D., Bower, K. N., Boudries, H., Canagaratna, M. R., Jimenez, J. L., Jayne, J. T., Garforth, A., Li, S.-M., and Worsnop, D. R.: Characterization of urban and regional organic aerosols in the lower Fraser Valley using two Aerodyne Aerosol Mass Spectrometers, Atmos. Environ., 38, 5745-5758, 2004.

Alfarra, M. R.: Insights into Atmospheric Organic Aerosols Using an Aerosol Mass Spectrometer, Ph.D. Dissertation, University of Manchester, 2004.

Allan, J. D., Alfarra, M. R., Bower, K. N., Williams, P. I., Gallagher, M. W., Jimenez, J. L., McDonald, A. G., Nemitz, E., Canagaratna, M. R., Jayne, J. T., Coe, H., and Worsnop, D. R.: Quantitative sampling using an Aerodyne Aerosol Mass Spectrometer, Part 2: Measurements of fine particulate chemical composition in two UK Cities, J. Geophys. Res., 108, 4091, doi:4010.1029/2002JD002359, 2003.

Allen, D. T., Palen, E. J., Haimov, M. I., Hering, S. V., and Young, J. R.: Fourier-Transform Infrared-Spectroscopy of aerosol collected in a Low-Pressure Impactor (LPI/FTIR) - Method development and field calibration, Aerosol Sci. Tech., 21, 25-342, 1994.

Atkinson, R. and Arey, J.: Atmospheric degradation of volatile organic compounds, Chem. Rev., 103, 4605-4638, 2003.

Bates, T. S., Quinn, P. K., Coffman, D. J., Johnson, J. E., and Middlebrook, A. M.: Dominance of organic aerosols in the marine boundary Layer over the Gulf of Maine during NEAQS 2002 and their role in aerosol light scattering, J. Geophys. Res., 110, D18202, doi:10.1029/2005JD005797, 2005.
Blando, J. D., Porcja, R. J., Li, T. H., Bowman, D., Lioy, P. J., and Turpin, B. J.: Secondary formation and the Smoky Mountain organic aerosol: An examination of aerosol polarity and functional group composition during SEAVS, Environ. Sci. Technol., 32, 604-613, 1998.

Blando, J. D. and Turpin, B. J.: Secondary organic aerosol formation in cloud and fog droplets: a literature evaluation of plausibility, Atmos. Environ., 34, 1623-1632, 2000.

CAM (Comision Ambiental Metropolitana): Inventario de Emisiones 2004 de la Zona Metropolitana del Valle de Mexico, Mexico, 2006.

Canagaratna, M. R., Jayne, J. T., Ghertner, D. A., Herndon, S., Shi, Q., Jimenez, J. L., Silva, P. J., Williams, P., Lanni, T., Drewnick, F., Demerjian, K. L., Kolb, C. E., and Worsnop, D. R.: Chase studies of particulate emissions from in-use New York city vehicles, Aerosol Sci. Tech., 38, 555-573, doi:510.1080/02786820490465504, 2004.

Canagaratna, M. R., Jayne, J. T., Jimenez, J. L., et al.: Chemical and Microphysical Characterization of Ambient Aerosols with the Aerodyne Aerosol Mass Spectrometer, Mass Spectrom. Rev., 26, 185-222, 2007.

Carter, W. P. L.: Programs and Files Implementing the SAPRC99 Mechanism and its Associates Emissions Processing Procedures for Models-3 and Other Regional Models: http://pah.cert. ucr.edu/ carter/SAPRC99.htm, last access: 31 January 2000.

Chow, J. C., Watson J. G., Edgerton, S. A., and Vega, E.: Chemical composition of $\mathrm{PM}_{2.5}$ and $\mathrm{PM}_{10}$ in Mexico City during winter 1997, Sci. Total Environ., 287, 177-201, 2002.

Chung, S. H. and Seinfeld, J. H.: Global distribution and climate forcing of carbonaceous aerosols, J. Geophys. Res.-Atmos., 107, 4407, doi:10.1029/2001JD001397, 2002.

Claeys, M., Wang, W., Ion, A. C., Kourtchev, I., Gelencser, A., and Maenhaut, W.: Formation of secondary organic aerosols from isoprene and its gas-phase oxidation products through reaction with hydrogen peroxide, Atmos. Environ., 38, 4093-4098, 2004.

Cooke, W. F., Liousse, C., Cachier, H., et al.: Construction of a 1 degrees $\times 1$ degrees fossil fuel emission data set for carbonaceous aerosol and implementation and radiative impact in the ECHAM4 model, J. Geophys. Res.-Atmos., 104, 22137-22162, 1999.

Corrigan, C. E. and Novakov, T.: Cloud condensation nucleus activity of organic compounds: a laboratory study, Atmos. Environ., 33, 2661-2668, 1999.

Cruz, C. N. and Pandis, S. N.: A study of the ability of pure secondary organic aerosol to act as cloud condensation nuclei, Atmos. Environ., 31, 2205-2214, 1997.

DeCarlo, P. F., Dunlea, E. J., Kimmel, J. R., Aiken, A. C., Sueper, D., Crounse, J., Wennberg, P. O., Emmons, L., Shinozuka, Y., Clarke, A., Zhou, J., Tomlinson, J., Collins, D. R., Knapp, D., Weinheimer, A. J., Montzka, D. D., Campos, T., and Jimenez, J. L.: Fast airborne aerosol size and chemistry measurements above Mexico City and Central Mexico during the MILAGRO campaign, Atmos. Chem. Phys., 8, 4027-4048, 2008, http://www.atmos-chem-phys.net/8/4027/2008/.

de Gouw, J. A., Middlebrook, A. M., Warneke, C., et al.: Budget of organic carbon in a polluted atmosphere: Results from the New England Air Quality Study in 2002, J. Geophys. Res.-Atmos., 110, D16305, doi:10.1029/2004JD005623, 2005. 
de Gouw, J. A., Welsh-Bon, D., Warneke, C., Kuster, W. C., Alexander, L., Baker, A. K., Beyersdorf, A. J., Blake, D. R., Canagaratna, M., Celada, A. T., Huey, L. G., Junkermann, W., Onasch, T. B., Salcido, A., Sjostedt, S. J., Sullivan, A. P., Tanner, D. J., Vargas, O., Weber, R. J., Worsnop, D. R., Yu, X. Y., and Zaveri, R.: Emission and chemistry of organic carbon in the gas and aerosol phase at a sub-urban site near Mexico City in March 2006 during the MILAGRO study, Atmos. Chem. Phys., 9, 3425-3442, 2009,

http://www.atmos-chem-phys.net/9/3425/2009/.

de Gouw, J. A. and Jimenez, J. L.: Organic Aerosols in the Earth's Atmosphere, Environ. Sci. Technol., 43, 7614-7618, 2009.

de Foy, B., Caetano, E., Magaña, V., Zitácuaro, A., Cárdenas, B., Retama, A., Ramos, R., Molina, L. T., and Molina, M. J.: Mexico City basin wind circulation during the MCMA-2003 field campaign, Atmos. Chem. Phys., 5, 2267-2288, 2005, http://www.atmos-chem-phys.net/5/2267/2005/.

Docherty, K. S., Stone, E. A., Ulbrich, I. M., et al.: Apportionment of Primary and Secondary Organic Aerosols in Southern California during the 2005 Study of Organic Aerosols in Riverside (SOAR-1), Environ. Sci. Technol., 42, 7655-7662, 2008.

Doran, J. C., Barnard, J. C., Arnott, W. P., Cary, R., Coulter, R., Fast, J. D., Kassianov, E. I., Kleinman, L., Laulainen, N. S., Martin, T., Paredes-Miranda, G., Pekour, M. S., Shaw, W. J., Smith, D. F., Springston, S. R., and Yu, X.-Y.: The T1-T2 study: evolution of aerosol properties downwind of Mexico City, Atmos. Chem. Phys., 7, 1585-1598, 2007, http://www.atmos-chem-phys.net/7/1585/2007/.

Donahue, N. M., Robinson, A. L., Stanier, C. O., and Pandis, S. N.: Coupled partitioning, dilution, and chemical aging of semivolatile organics, Environ. Sci. Technol., 40, 2635-2643, 2006.

Donahue, N. M., Robinson, A. L., and Pandis, S. N.: Atmospheric organic particulate matter: From smoke to secondary organic aerosol, Atmos. Environ., 43, 94-106, 2009.

Dzepina, K., Volkamer, R. M., Madronich, S., Tulet, P., Ulbrich, I. M., Zhang, Q., Cappa, C. D., Ziemann, P. J., and Jimenez, J. L.: Evaluation of recently-proposed secondary organic aerosol models for a case study in Mexico City, Atmos. Chem. Phys., 9, 5681-5709, 2009, http://www.atmos-chem-phys.net/9/5681/2009/.

Edgerton, S. A., Bian, X., Doran, J. C., et al.: Particulate air pollution in Mexico City: A collaborative research project, J. Air Waste Manage., 49, 1221-1229, 1999.

Environ: User's guide to the comprehensive air quality model with extensions (CAMx), version 4.02, Report prepared by ENVIRON Int. Corp., Novato, CA, 2003.

Environ: User's guide to the comprehensive air quality model with extensions (CAMx), Version 4.50, Report prepared by ENVIRON Int. Corp., Novato, CA, 2008.

EPA: Community Multiscale Air Quality (CMAQ) Modeling System, US Environmental Protection Agency, http://www.epa. gov/asmdnerl/CMAQ/CMAQscienceDoc.html, last access: January 2009.

Fahey, K. M. and Pandis, S. N.: Optimizing model performance: Variable size resolution in cloud chemistry modelling, Atmos. Environ., 35, 4471-4478, 2001.

Fast, J., Aiken, A. C., Allan, J., Alexander, L., Campos, T., Canagaratna, M. R., Chapman, E., DeCarlo, P. F., de Foy, B., Gaffney,
J., de Gouw, J., Doran, J. C., Emmons, L., Hodzic, A., Herndon, S. C., Huey, G., Jayne, J. T., Jimenez, J. L., Kleinman, L., Kuster, W., Marley, N., Russell, L., Ochoa, C., Onasch, T. B., Pekour, M., Song, C., Ulbrich, I. M., Warneke, C., Welsh-Bon, D., Wiedinmyer, C., Worsnop, D. R., Yu, X.-Y., and Zaveri, R.: Evaluating simulated primary anthropogenic and biomass burning organic aerosols during MILAGRO: implications for assessing treatments of secondary organic aerosols, Atmos. Chem. Phys., 9, 6191-6215, 2009,

http://www.atmos-chem-phys.net/9/6191/2009/.

Feng, J. L., Hu, M., Chan, C. K., et al.: A comparative study of the organic matter in $\mathrm{PM}_{2.5}$ from three Chinese megacities in three different climatic zones, Atmos. Environ., 40, 3983-3994, 2006.

Gaydos, T. M., Koo, B., Pandis, S. N., and Chock, D. P.: Development and application of an efficient moving sectional approach for the solution of the atmospheric aerosol condensation/evaporation equations, Atmos. Environ., 37, 3303-3316, 2003.

Gaydos, T. M., Pinder, R. W., Koo, B., Fahey, K. M., and Pandis, S. N.: Development and application of a three-dimensional aerosol chemical transport model, PMCAMx, Atmos. Environ., 41, 2594-2611, 2007.

Grell, G. A., Dudhia, J., and Stauffer, D. R.: A Description of the Fifth-Generation Penn State/NCAR Mesoscale Model (MM5), Tech. Rep. NCAR/TN-398+STR, NCAR, 1995.

Hallquist, M., Wenger, J. C., Baltensperger, U., Rudich, Y., Simpson, D., Claeys, M., Dommen, J., Donahue, N. M., George, C., Goldstein, A. H., Hamilton, J. F., Herrmann, H., Hoffmann, T., Iinuma, Y., Jang, M., Jenkin, M. E., Jimenez, J. L., Kiendler-Scharr, A., Maenhaut, W., McFiggans, G., Mentel, Th. F., Monod, A., Prévôt, A. S. H., Seinfeld, J. H., Surratt, J. D., Szmigielski, R., and Wildt, J.: The formation, properties and impact of secondary organic aerosol: current and emerging issues, Atmos. Chem. Phys., 9, 5155-5235, 2009, http://www.atmos-chem-phys.net/9/5155/2009/.

Hildebrandt, L., Donahue, N. M., and Pandis, S. N.: High formation of secondary organic aerosol from the photo-oxidation of toluene, Atmos. Chem. Phys., 9, 2973-2986, 2009, http://www.atmos-chem-phys.net/9/2973/2009/.

Hildemann, L. M., Cass, G. R., and Markowski, G. R.: A dilution stack sampler for collection of organic aerosol emissions - design, characterization and field-tests, Aeros. Sci. Tech., 10, 193204, 1989.

Hodzic, A., Jimenez, J. L., Madronich, S., Aiken, A. C., Bessagnet, B., Curci, G., Fast, J., Lamarque, J.-F., Onasch, T. B., Roux, G., Schauer, J. J., Stone, E. A., and Ulbrich, I. M.: Modeling organic aerosols during MILAGRO: importance of biogenic secondary organic aerosols, Atmos. Chem. Phys., 9, 6949-6981, 2009, http://www.atmos-chem-phys.net/9/6949/2009/.

Huffman, J. A., Docherty, K. S., Mohr, C., Cubison, M. J., U1brich, I. M., Ziemann, P. J., Onasch, T. B., and Jimenez, J. L.: Chemically-resolved volatility measurements of organic aerosol from different sources, Environ. Sci. Technol., 43, 5351-5357, 2009a.

Huffman, J. A., Docherty, K. S., Aiken, A. C., Cubison, M. J., U1brich, I. M., DeCarlo, P. F., Sueper, D., Jayne, J. T., Worsnop, D. R., Ziemann, P. J., and Jimenez, J. L.: Chemically-resolved aerosol volatility measurements from two megacity field studies, Atmos. Chem. Phys., 9, 7161-7182, 2009b, 
http://www.atmos-chem-phys.net/9/7161/2009/.

Jacobson, M. C., Hansson, H. C., Noone, K. J., and Charlson, R. J.: Organic atmospheric aerosols: Review and state of the science, Rev. Geophys., 38, 267-294, 2000.

Jang, M. S., Czoschke, N. M., Lee, S., and Kamens, R. M.: Heterogeneous atmospheric aerosol production by acid-catalyzed particle-phase reactions, Science, 298, 814-817, 2002.

Jauregui, E.: Local wind and air pollution interaction in the Mexico basin, Atmosfera, 1, 131-140, 1988.

Jayne, J. T., Leard, D. C., Zhang, X., Davidovits, P., Smith, K. A., Kolb, C. E., and Worsnop, D. R.: Development of an Aerosol Mass Spectrometer for Size and Composition Analysis of Submicron Particles, Aerosol Sci. Tech., 33, 49-70, 2000.

Jimenez, J. L., Jayne, J. T., Shi, Q., Kolb, C. E., Worsnop, D. R., Yourshaw, I., Seinfeld, J. H., Flagan, R. C., Zhang, X., Smith, K. A., Morris, J., and Davidovits, P.: Ambient aerosol sampling using the Aerodyne Aerosol Mass Spectrometer, J. Geophys. Res., 108, 8425, doi:10.1029/2001JD001213, 2003.

Johnson, K. S., de Foy, B., Zuberi, B., Molina, L. T., Molina, M. J., Xie, Y., Laskin, A., and Shutthanandan, V.: Aerosol composition and source apportionment in the Mexico City Metropolitan Area with PIXE/PESA/STIM and multivariate analysis, Atmos. Chem. Phys., 6, 4591-4600, 2006,

http://www.atmos-chem-phys.net/6/4591/2006/.

Johnson, K. S., Laskin, A., Jimenez, J. L., et al.: Comparative analysis of urban atmospheric aerosol by Proton-Induced X-ray Emission (PIXE), Proton Elastic Scattering Analysis (PESA), and Aerosol Mass Spectrometry (AMS), Environ. Sci. Technol., 42, 6619-6624, 2008.

Kanakidou, M., Seinfeld, J. H., Pandis, S. N., Barnes, I., Dentener, F. J., Facchini, M. C., Van Dingenen, R., Ervens, B., Nenes, A., Nielsen, C. J., Swietlicki, E., Putaud, J. P., Balkanski, Y., Fuzzi, S., Horth, J., Moortgat, G. K., Winterhalter, R., Myhre, C. E. L., Tsigaridis, K., Vignati, E., Stephanou, E. G., and Wilson, J.: Organic aerosol and global climate modelling: a review, Atmos. Chem. Phys., 5, 1053-1123, 2005, http://www.atmos-chem-phys.net/5/1053/2005/.

Kavouras, I. G. and Stephanou, E. G.: Particle size distribution of organic primary and secondary aerosol constituents in urban, background marine, and forest atmosphere, J. Geophys. Res., 107, 4069, doi:10.1029/2000JD000278, 2002.

Kerminen, V. M., Virkkula, A., Hillamo, R., Wexler, A. S., and Kulmala, M.: Secondary organics and atmospheric cloud condensation nuclei production, J. Geophys. Res., 105, 9255-9264, 2000.

Kleinman, L. I., Springston, S. R., Daum, P. H., Lee, Y.-N., Nunnermacker, L. J., Senum, G. I., Wang, J., Weinstein-Lloyd, J., Alexander, M. L., Hubbe, J., Ortega, J., Canagaratna, M. R., and Jayne, J.: The time evolution of aerosol composition over the Mexico City plateau, Atmos. Chem. Phys., 8, 1559-1575, 2008, http://www.atmos-chem-phys.net/8/1559/2008/.

Koo, B. Y., Ansari, A. S., and Pandis, S. N.: Integrated approaches to modeling the organic and inorganic atmospheric aerosol components, Atmos. Environ., 37, 4757-4768, 2003.

Kroll, J. H., Ng, N. L., Murphy, S. M., Flagan, R. C., and Seinfeld, J. H.: Secondary organic aerosol formation from isoprene photooxidation, Environ. Sci. Technol., 40, 155-162, 2006.

Kuhn, T., Biswas, S., Fine, P. M., Geller, M., and Sioutas, C.: Physical and chemical characteristics and volatility of PM in the proximity of a light-duty vehicle freeway, Aerosol Sci. Tech., 39, 347-357, 2005.

Lane, T. E., Donahue, N. M., and Pandis, S. N.: Simulating Secondary Organic Aerosol Formation using the Volatility Basis-Set Approach in a Chemical Transport Model, Atmos. Environ., 42, 7439-7451, 2008a.

Lane, T. E., Donahue, N. M., and Pandis, S. N.: Effect of $\mathrm{NO}_{\mathrm{x}}$ on secondary organic aerosol concentrations, Environ. Sci. Technol., 42, 6022-6027, 2008b.

Lanz, V. A., Alfarra, M. R., Baltensperger, U., Buchmann, B., Hueglin, C., and Prévôt, A. S. H.: Source apportionment of submicron organic aerosols at an urban site by factor analytical modelling of aerosol mass spectra, Atmos. Chem. Phys., 7, 1503-1522, 2007, http://www.atmos-chem-phys.net/7/1503/2007/.

Lei, W., de Foy, B., Zavala, M., Volkamer, R., and Molina, L. T.: Characterizing ozone production in the Mexico City Metropolitan Area: a case study using a chemical transport model, Atmos. Chem. Phys., 7, 1347-1366, 2007, http://www.atmos-chem-phys.net/7/1347/2007/.

Lei, W., Zavala, M., de Foy, B., Volkamer, R., and Molina, L. T.: Characterizing ozone production and response under different meteorological conditions in Mexico City, Atmos. Chem. Phys., 8, 7571-7581, 2008, http://www.atmos-chem-phys.net/8/7571/2008/.

Lei, W., Zavala, M., de Foy, B., Volkamer, R., Molina, M. J., and Molina, L. T.: Impact of primary formaldehyde on air pollution in the Mexico City Metropolitan Area, Atmos. Chem. Phys., 9, 2607-2618, 2009,

http://www.atmos-chem-phys.net/9/2607/2009/.

Lipsky, E. M. and Robinson, A. L.: Effects of dilution on fine particle mass and partitioning of semivolatile organics in diesel exhaust and wood smoke, Environ. Sci. Technol., 40, 55-162, 2006.

Mao, J., Ren, X., Chen, S., Brune, W. H., Chen, Z., Martinez, M., Harder, H., Lefer, B., Rappenglück, B., and Flynn, J.: Atmospheric oxidation capacity in the summer of Houston 2006: Comparison with Summer Measurements in Other Metropolitan Studies, Atmos. Environ., in press, doi:10.1016/j.atmosenv.2009.01.01, 2009.

Matsui, H., Koike, M., Takegawa, N., et al.: Secondary organic aerosol formation in urban air: Temporal variations and possible contributions from unidentified hydrocarbons, J. Geophys. Res., 114, D04201, doi:10.1029/2008JD010164, 2009.

McKeown, P. J., Johnston, M. V., and Murphy, D. M.: Online single-particle analysis by Laser Desorption Mass-Spectrometry, Anal. Chem., 63, 2069-2073, 1991.

Mircea, M., Facchini, M. C., Decesari, S., Fuzzi, S., and Charlson, R. J.: The influence of the organic aerosol component on CCN supersaturation spectra for different aerosol types, Tellus B, 54, 74-81, 2002.

Mohr, C., Huffman, J. A., Cubison, M. J., et al.: Characterization of Primary Organic Aerosol Emissions from Meat Cooking, Trash Burning, and Motor Vehicles with High-Resolution Aerosol Mass Spectrometry and Comparison with Ambient and Chamber Observations, Environ. Sci. Technol., 43, 2443-2449, doi:10.1021/es8011518, 2009. 
Molina, L. T., Kolb, C. E., de Foy, B., Lamb, B. K., Brune, W. H., Jimenez, J. L., Ramos-Villegas, R., Sarmiento, J., ParamoFigueroa, V. H., Cardenas, B., Gutierrez-Avedoy, V., and Molina, M. J.: Air quality in North America's most populous city overview of the MCMA-2003 campaign, Atmos. Chem. Phys., 7, 2447-2473, 2007,

http://www.atmos-chem-phys.net/7/2447/2007/.

Morris, R. E., Koo, B., Guenther, A., Yarwood, G., McNally, D., Tesche, T. W., Tonnesen, G., Boylan, J., and Brewer, P.: Model sensitivity evaluation for organic carbon using two multipollutant air quality models that simulate regional haze in the southeastern United States, Atmos. Environ., 40, 4960-4972, 2006.

Murphy, D. M., Cziczo, D. J., Froyd, K. D., et al.: Single-particle mass spectrometry of tropospheric aerosol particles, J. Geophys. Res., 111, D23S32, doi:10.1029/2006JD007340, 2006.

NARSTO: Particulate Matter Science for Policy Makers: A NARSTO Assessment, EPRI 1007735, 2003.

Nemitz, E., Jimenez, J. L., Huffman, J. A., Canagaratna, M. R., Worsnop, D. R., and Guenther, A. B.: An eddy-covariance system for the measurement of surface/atmosphere exchange fluxes of submicron aerosol chemical species - first application above an urban area, Aerosol Sci. Tech., 42, 636-657, 2008.

Ng, N. L., Kroll, J. H., Keywood, M. D., Bahreini, R., Varutbangkul, V., Flagan, R. C., and Seinfeld, J. H.: Contribution of first- versus second-generation products to secondary organic aerosols formed in the oxidation of biogenic hydrocarbons, Environ. Sci. Technol., 40, 2283-2297, 2006.

Odum, J. R., Hoffman, T., Bowman, F., Collins, D., Flagan, R. C., and Seinfeld, J. H.: Gas/particle partitioning and secondary organic aerosol yields, Environ. Sci. Technol., 30, 2580-2585, 1996.

Paatero, P. and Tapper, U.: Positive matrix factorization: a nonnegative factor model with optimal utilization of error estimates of data values, Environmetrics, 5, 111-126, 1994.

Paatero, P.: Least squares formulation of robust non-negative factor analysis, Chemometr. Intell. Lab., 37, 23-35, 1997.

Pandis, S. N., Paulson, S. E., Seinfeld, J. H., and Flagan, R. C.: Aerosol formation in the photooxidation of isoprene and $\beta$ pinene, Atmos. Environ., 25A, 997-1008, 1991.

Pandis, S. N., Harley, R. A., Cass, G. R., and Seinfeld, J. H.: Secondary organic aerosol formation and transport, Atmos. Environ., 26, 2269-2282, 1992.

Putaud, J. P., Raes, F., Van Dingenen, R., Brüggemann, E., Facchini, M. C., Decesari, S., Fuzzi, S., Gehrig, R., Huglin, C., Laj, P., Lorbeer, G., Maenhaut, W., Mihalopoulos, N., Müller, K., Querol, X., Rodriguez, S., Schneider, J., Spindler, G., ten Brink, H., Tørseth, K., and Wiedensohler, A.: A European aerosol phenomenology 2: chemical characteristics of particulate matter at kerbside, urban, rural and background sites in Europe, Atmos. Environ., 38, 2579-2595, 2004.

Robinson, A. L., Donahue, N. M., Shrivastava, M. K., Weitkamp, E. A., Sage, A. M., Grieshop, A. P., Lane, T. E., Pandis, S. N., and Pierce, J. R.: Rethinking organic aerosols: semivolatile emissions and photochemical aging, Science, 315, 1259-1262, 2007.

Russell, A. and Dennis, R.: NARSTO critical review of photochemical models and modeling, Atmos. Environ., 34, 2283-2324, 2000 .
Salcedo, D., Onasch, T. B., Dzepina, K., Canagaratna, M. R., Zhang, Q., Huffman, J. A., DeCarlo, P. F., Jayne, J. T., Mortimer, P., Worsnop, D. R., Kolb, C. E., Johnson, K. S., Zuberi, B., Marr, L. C., Volkamer, R., Molina, L. T., Molina, M. J., Cardenas, B., Bernabé, R. M., Márquez, C., Gaffney, J. S., Marley, N. A., Laskin, A., Shutthanandan, V., Xie, Y., Brune, W., Lesher, R., Shirley, T., and Jimenez, J. L.: Characterization of ambient aerosols in Mexico City during the MCMA-2003 campaign with Aerosol Mass Spectrometry: results from the CENICA Supersite, Atmos. Chem. Phys., 6, 925-946, 2006,

http://www.atmos-chem-phys.net/6/925/2006/.

Salcedo, D., Onasch, T. B., Canagaratna, M. R., Dzepina, K., Huffman, J. A., Jayne, J. T., Worsnop, D. R., Kolb, C. E., Weimer, S., Drewnick, F., Allan, J. D., Delia, A. E., and Jimenez, J. L.: Technical Note: Use of a beam width probe in an Aerosol Mass Spectrometer to monitor particle collection efficiency in the field, Atmos. Chem. Phys., 7, 549-556, 2007, http://www.atmos-chem-phys.net/7/549/2007/.

Saxena, P. and Hildemann, L. M.: Water-Soluble Organics in Atmospheric Particles: A Critical Review of the Literature and Application of Thermodynamics to Identify Candidate Compounds, J. Atmos. Chem., 24, 57-109, 1996.

Schauer, J. J., Rogge, W. F., Hildemann, L. M., Mazurek, M. A., and Cass, G. R.: Source apportionment of airborne particulate matter using organic compounds as tracers, Atmos. Environ., 30, 3837-3855, 1996.

Schauer, J. J., Kleeman, M. J., Cass, G. R., and Simoneit, B. R. T.: Measurement of emissions from air pollution sources, 2. C1 through C-30 organic compounds from medium duty diesel trucks, Environ. Sci. Technol., 33, 1578-1587, 1999.

Schauer, J. J., Kleeman, M. J., Cass, G. R., and Simoneit, B. R. T.: Measurement of emissions from air pollution sources, 3. C1-C-29 organic compounds from fireplace combustion of wood, Environ. Sci. Technol., 35, 1716-1728, 2001.

Schauer, J. J., Kleeman, M. J., Cass, G. R., and Simoneit, B. R. T. Measurement of emissions from air pollution sources, 5. C-1-C32 organic compounds from gasoline-powered motor vehicles, Environ. Sci. Technol., 36, 1169-1180, 2002.

Seinfeld, J. H. and Pankow, J. F.: Organic atmospheric particulate material, Ann. Rev. Phys. Chem., 54, 121-140, 2003.

Sheehy, P. M., Volkamer, R., Molina, L. T., and Molina, M. J.: Oxidative capacity of the Mexico City atmosphere - Part 2: A $\mathrm{RO}_{\mathrm{x}}$ radical cycling perspective, Atmos. Chem. Phys. Discuss., 8, 5359-5412, 2008,

http://www.atmos-chem-phys-discuss.net/8/5359/2008/.

Shirley, T. R., Brune, W. H., Ren, X., Mao, J., Lesher, R., Cardenas, B., Volkamer, R., Molina, L. T., Molina, M. J., Lamb, B., Velasco, E., Jobson, T., and Alexander, M.: Atmospheric oxidation in the Mexico City Metropolitan Area (MCMA) during April 2003, Atmos. Chem. Phys., 6, 2753-2765, 2006, http://www.atmos-chem-phys.net/6/2753/2006/.

Shrivastava, M. K., Lane, T. E., Donahue, N. M., Pandis, S. N., and Robinson, A. L.: Effects of gas-particle partitioning and aging of primary emissions on urban and regional organic aerosol concentrations, J. Geophys. Res., 113, D18301, doi:10.1029/2007JD009735, 2008.

Song, C., Zaveri, R. A., Alexander, M. L., Thornton, J. A., Madronich, S., Ortega, J. V., Zelenyuk, A., Yu, X. Y., Laskin, A., and Maughan, D. A.: Effect of hydrophobic primary 
organic aerosols on secondary organic aerosol formation from ozonolysis of $\alpha$-pinene, Geophys. Res. Lett., 34, L20803, doi:10.1029/2007GL030720, 2007.

Stanier, C. O., Donahue, N., and Pandis, S. N.: Parameterization of secondary organic aerosol mass fractions from smog chamber data, Atmos. Environ., 42, 4849-4863, 2008.

Strader, R., Lurmann, F., and Pandis, S. N.: Evaluation of secondary organic aerosol formation in winter, Atmos. Environ., 33, 48494863, 1999.

Stone, E. A., Snyder, D. C., Sheesley, R. J., Sullivan, A. P., Weber, R. J., and Schauer, J. J.: Source apportionment of fine organic aerosol in Mexico City during the MILAGRO experiment 2006, Atmos. Chem. Phys., 8, 1249-1259, 2008, http://www.atmos-chem-phys.net/8/1249/2008/.

Suess, D. T. and Prather, K. A.: Mass spectrometry of aerosols, Chem. Rev., 99, 3007, 1999.

Takegawa, N., Miyazaki, Y., Kondo, Y., Komazaki, Y., Miyakawa, T., Jimenez, J. L., Jayne, J. T., Worsnop, D. R., Allan, J., and Weber, R. J.: Characterization of an Aerodyne Aerosol Mass Spectrometer (AMS): Intercomparison with other aerosol instruments, Aeros. Sci. Tech., 39, 760-770, 2005.

Ulbrich, I. M., Canagaratna, M. R., Zhang, Q., Worsnop, D. R., and Jimenez, J. L.: Interpretation of organic components from Positive Matrix Factorization of aerosol mass spectrometric data, Atmos. Chem. Phys., 9, 2891-2918, 2009, http://www.atmos-chem-phys.net/9/2891/2009/.

Volkamer, R., Jimenez, J. L., San Martini, F., et al.: Secondary organic aerosol formation from anthropogenic air pollution: Rapid and higher than expected, Geophys. Res. Lett., 33, L17811, doi:10.1029/2006GL026899, 2006.

Volkamer, R., San Martini, F., Molina, L. T., et al.: A Missing Sink for Gas-Phase Glyoxal in Mexico City: Formation of Secondary Organic Aerosol, Geophys. Res. Lett., 34, L19807, doi:10.1029/2007GL030752, 2007.
Volkamer, R., Ziemann, P. J., and Molina, M. J.: Secondary Organic Aerosol Formation from Acetylene $\left(\mathrm{C}_{2} \mathrm{H}_{2}\right)$ : seed effect on SOA yields due to organic photochemistry in the aerosol aqueous phase, Atmos. Chem. Phys., 9, 1907-1928, 2009, http://www.atmos-chem-phys.net/9/1907/2009/.

Wesely, M. L.: Parameterization of surface resistances to gaseous dry deposition in regional-scale numerical models, Atmos. Environ., 23, 1293-1304, 1989.

Yu, S., Dennis, R., Roselle, S., Nenes, A., Walker, J., Eder, B., Schere, K., Swall, J., and Robarge, W.: An assessment of the ability of three-dimensional air quality models with current thermodynamic equilibrium models to predict aerosol $\mathrm{NO}_{3}^{-}$, J. Geophys. Res., 110, D07S13, doi:10.1029/2004JD004718, 2005.

Zhang, Q., Stanier, C. O., Canagaratna, M. R., Jayne, J. T., Worsnop, D. R., Pandis, S. N., and Jimenez, J. L.: Insights into the chemistry of new particle formation and growth events in Pittsburgh based on Aerosol Mass Spectrometry, Environ. Sci. Technol., 38, 4797-4809, 2004.

Zhang, Q., Worsnop, D. R., Canagaratna, M. R., and Jimenez, J. L.: Hydrocarbon-like and oxygenated organic aerosols in Pittsburgh: insights into sources and processes of organic aerosols, Atmos. Chem. Phys., 5, 3289-3311, 2005, http://www.atmos-chem-phys.net/5/3289/2005/.

Zhang, Q., Canagaratna, M. C., Jayne, J. T., Worsnop, D. R., and Jimenez, J. L: Time and size-resolved chemical composition of submicron particles in Pittsburgh Implications for aerosol sources and processes, J. Geophys. Res., 110, D07S09, doi:10.1029/2004JD004649, 2005b.

Zhang, Q., Jimenez, J. L., Canagaratna, M. R., et al.: Ubiquity and dominance of oxygenated species in organic aerosols in anthropogenically-influenced Northern Hemisphere midlatitudes, Geophys. Res. Lett., 34, L13801, doi:10.1029/2007GL029979, 2007. 